Article

\title{
New Housing Complexes in Post-Industrial Areas in City Centres in Poland Versus Cultural and Natural Heritage Protection-With a Particular Focus on Cracow
}

\author{
Mateusz Gyurkovich *(D) and Jacek Gyurkovich (D) \\ Chair of Urbanism and City Structure Architecture, Faculty of Architecture, Cracow University of Technology, \\ 31-155 Cracow, Poland; jgyurkovich@pk.edu.pl \\ * Correspondence: mateusz.gyurkovich@pk.edu.pl; Tel.: +48-606-605-272
}

check for updates

Citation: Gyurkovich, M.; Gyurkovich, J. New Housing Complexes in Post-Industrial Areas in City Centres in Poland Versus Cultural and Natural Heritage Protection-With a Particular Focus on Cracow. Sustainability 2021, 13, 418. http:/ / doi.org/10.3390/su13010418

Received: 17 November 2020 Accepted: 29 December 2020 Published: 5 January 2021

Publisher's Note: MDPI stays neutral with regard to jurisdictional clai$\mathrm{ms}$ in published maps and institutional affiliations.

Copyright: (C) 2021 by the authors. Licensee MDPI, Basel, Switzerland. This article is an open access article distributed under the terms and conditions of the Creative Commons Attribution (CC BY) license (https:// creativecommons.org/licenses/by/ $4.0 /)$.

\begin{abstract}
The cityscape changes constantly, reflecting the socio-economic conditions of a given urbanised area-both globally and in any given country. Post-industrial buildings and complexes have been its important elements since the nineteenth century. At present, many of them are undergoing adaptive reuse. The oldest, which are parts of post-industrial heritage and define the local identity, are now located in city centres. Some are revitalised and often adapted into multifamily housing. This paper fills a gap in the research on revitalised areas in Polish city centres, especially the ones converted into housing. It notes the links between these projects with elements of urban green-blue infrastructure, as well as the methods of protection of the reused postindustrial heritage. Studies from 2000-2020 on Polish multi-family housing architecture prove that the quality of buildings and semi-public green spaces is becoming increasingly important to developers and buyers. Properly used and exposed post-industrial heritage can contribute to raising the attractiveness of such spaces. In combination with city greenery systems, they can form attractive townscape sequences, as proven by Cracow cases. The paper's conclusions indicate that the preservation and exposition of post-industrial heritage in newly built housing complexes is affected by numerous factors. The most important of these are legal determinants based on both state-level and local law. Economic factors also play a major role, as they directly affect projects. The skills and talent of designers who can create unique proposals that expose surviving relicts and a given place's genius loci even in the most restrictive of economic and legal conditions, are also not without significance.
\end{abstract}

Keywords: urban renewal; post-industrial heritage; multi-family housing; revitalisation of city centres; protection and preservation of built heritage; blue-green infrastructure of a city; Polish major cities; Cracow

\section{Introduction}

The need for living and residing in confined and safe areas has been a part of human nature for millennia. The first cities to be documented by archaeological studies appeared seven thousand years ago [1]. Some have survived to the present, yet those that had been destroyed were continuously being replaced by new ones. Humans settled in new, previously virgin areas and continue to do so. This process appears to be increasingly dynamic and thus generates negative consequences for the natural environment. The spatial structures of cities have changed over time, along with new needs and ideas generated by increasingly complex societies. Better and more complex urban forms emerged as a response to these changes [2]. Over the centuries, the city became the natural environment of human life [3], and the twentieth century specifically was proclaimed the century of cities. At present, already half of the world's population lives in cities, as demonstrated by numerous academic reports and statistical studies. It is projected that $75 \%$ of the world's population will live in cities by 2050. Forecasts also note the global phenomenon of shrinking cities as clearly regressing, while over $90 \%$ of the one thousand of the world's 
largest cities continue to increase their populations [4,5]. Despite European cities ranking increasingly lower in these types of lists (the first fifty positions for 2020 only included four European metropolises: Istanbul, Moscow, Paris and London, while four Polish cities were listed in the first thousand: Warsaw, Cracow, Łódź and Wrocław), the share of city dwellers in the continent's population is much higher. A European Commission report from 2006 stated that, at the time of its publication, as much as $75 \%$ of the European Union's population inhabited urbanised areas: cities and urban functional areas, including metropolitan ones [6]. Thus, the primary function of cities appears to be housing, yet they would not be able to function correctly without other programmatic elements which attract new residents. Cities can also be treated as systems that comprise numerous subsystems (natural and man-made) that either are or can turn out to be some of the most perfect known achievements of human civilisation [7]. The city and the phenomena that take place within them remain in the field of interest of many specialists who represent disciplines like psychology, sociology, architecture, history, geography or traffic engineering. Urban design is an interdisciplinary field [8], which provides multi-track opportunities for research [9].

In the discussion engaged in the paper, we use fundamental notions of cultural heritage and natural heritage which, as argued by Lowenthal [10], form humanity's legacy. The former is typically understood as the entirety of humanity's tangible and intangible achievements [11]. Urban heritage is a specific case of this and is of interest to the presented work [12]. Elements of architectural and urban heritage contribute to the urban form of the contemporary city, along with new additions [13]. Despite numerous scholars' understanding of natural heritage solely as nature unaltered by man, it is difficult to find truly wild areas in Europe. Therefore, it is assumed that areas that are partially landscaped or created by humans should be acknowledged as elements of natural heritage [10,14]. This reasoning is justified by the fact that even in city parks, created by humans, and often in post-industrial areas, separate, even niche ecosystems can develop [15]. They can contribute to ecological linkages on the regional and sometimes even the supraregional scale [16]. They also cross urban and metropolitan areas, including the area discussed in this paper [17].

This research includes studies of the development and transformation of housing areas in cities. These studies focus both on their design in a compositional harmony with the urban spatial layout $[18,19]$ and on the context of the optimal use of natural resources and the reclamation of already developed areas [20-22]. Experience collected in the twentieth century demonstrated that large, monofunctional housing estates were often erected without the necessary educational, service or transport infrastructure [23]. They were built all over Europe after the Second World War as an answer to the demand caused by the new social and political situation [24]. The long-term consequences of these projects led to social and spatial pathologies, which have been identified and investigated only relatively recently $[25,26]$, particularly in the countries of Central and Eastern Europe. Numerous measures have been taken to improve this situation and create multi-functional areas that can satisfy the needs of local communities [27]. The findings of studies that have been published for several decades all over the world, by presenting diagnoses and proposals of solutions, can contribute to a more sustainable urban development and the elimination of adverse phenomena such as urban shrinkage or urban sprawl [28-32]. In this context, efforts must be made to reclaim and reuse already developed areas inside cities, especially brownfields [33], by both developing and enhancing the network of blue-green linkages in these areas wherever possible [34].

This paper is a result of many years of study of the built environment, including multifamily housing complexes. The authors have continuously studied cities and urban housing areas in Poland and Western Europe for several decades. One of the foci of this research were areas built in post-industrial areas. In the years 2000-2020, comparative analyses of several dozens of new multi-family housing developments were performed in the five largest urban centres and metropolitan areas of Poland (Warsaw, Cracow, Łódź, Wrocław, the Tri-city: Gdańsk-Sopot-Gdynia). Among the projects that were analysed-ranging 
from singular multi-family residential buildings to complexes of varying size-those built in post-industrial areas located in city centres deserve particular attention. This paper fills a gap in the state of the art concerning revitalised areas in the centres of Polish cities, focusing on the linkages between these projects and elements of urban green-blue infrastructure [35], as well as the degree of protection and exposure of post-industrial heritage elements. To keep the text short, only cases from Cracow were discussed in this particular paper.

\section{Materials and Methods}

The methodology used in the study included the follow tools: an analysis of the literature (including printed and online sources), archival queries and analyses of the city's reports and planning documents, including documents associated with the protection of natural and cultural heritage. The study also covered historical texts and reports, applicable documents and policies, as well as drafts of documents available for public and expert consultation. Urban analysis, performed in the form of numerous site visits, was the primary research tool. The confrontation of the findings from site visits with applicable planning documents and the results of previous global and domestic studies, was crucial in formulating the study's findings.

The study presented here covered new residential buildings and complexes that are characterised by: a site with a post-industrial past, proximity to historical urban tissue and to elements of the city's blue-green infrastructure. Each of the analysed buildings and complexes was examined in situ. This enabled the collection of photographic documentation, which proved useful in the analyses that followed. Furthermore, based on available maps and surveying materials (procured online, from municipal institutions and design firms) the urban analyses of development structure were performed (based on a figure-ground plan): development height, public space structure, the green space system, the hydrological system (surface waters) and the vehicular and public transport layout. The composition of the layout was carefully analysed. Focused primarily on morphological changes in reference to the form of the city prior to and after the transformation, both in regard to the fragments under study and the entire structure. The focus was also placed on the formation of proper compositional and functional linkages with the spatial context including-wherever possible-green areas of significance to ensuring a healthy housing environment [14]. These areas-both in a landscaped and natural state-often constitute elements of natural heritage of the city, that are important on the urban or regional scale.

One of the goals of the study was to determine how elements of cultural heritage, most importantly those associated with previous land use (industrial or infrastructural) affected the character of architecture and land development in the projects under study. While performing this task, we studied maps and archival photographs, available both online [36] and in archives. We surveyed the literature: academic and popularising texts as well as source documents. We examined multi-family residential buildings and complexes built in post-industrial areas in the centre of Cracow. The analysis of applicable and historical planning documents played a major part in the study. We analysed applicable documents and listings concerning the city's heritage. Some of these elements were also discussed in the literature [37-41].

The literature that we based our study on and cited in the paper discusses the development of urban structures and urban composition, with a particular emphasis on European and Polish cities, as well as Cracow. Many items discussed the transformation of postindustrial areas, both in Europe and Poland, as well as housing buildings and complexes and their relationship with blue-green infrastructure. Some of the cited items reference definitions of fundamental notions linked with the subject under study (cultural heritage, natural heritage, architectural and urban heritage, blue-green infrastructure and housing environment). Others discuss the cases under study directly. In this context, we also cited applicable legal acts, including acts of local law (local spatial development plans-MPZP) as well as published planning documents concerning Cracow that we used in the study, 
and which were mostly available online. We have referenced these documents throughout the entirety of this paper.

\section{Post-Industrial Areas in the Inner-Cities}

\subsection{Potential of Post-Industrial Areas in European Cities}

Civilisational changes and the associated processes of urbanisation have altered the landscape of Europe-particularly its cityscapes and townscapes-several times over the past two centuries [42,43]. The European city, which has been evolving for several thousand years, has failed to produce a single commonly applicable spatial model, which appears to be both its strength and distinguishing feature [44-46]. However, it has created a certain set of characteristics and a hierarchical system of public spaces that make it recognisable $[47,48]$. These are the public buildings and housing tissue that act as its fundamental components along with the public spaces that bind them-and which have a varied typology and purpose. In addition, in many cities it is industrial and storage areas, primarily nineteenth- and twentieth-century factory and storage yard grounds, that are the most valuable elements of cultural heritage. Due to socio-economic changes, including the global pursuit of cheaper production solutions or the shutting down of manufacturing in favour of the creative sector [49], these areas became abandoned. They freed up areas seen as attractive for development and that were relatively close to historical city centres-areas that should have been reclaimed for cities [50]. In comparison to dynamically developing western countries, in Poland, these changes typically play out with a certain delay and do so at a slower pace, reflecting the general political and historical situation.

In the nineteenth century, it was the partitions that exerted a major impact on the uneven urbanisation of the present-day territory of Poland and the different development patterns of each city. During this period, what is now Poland was divided between foreign powers-Prussia, Russia and Austria (in the years 1795-1918, although this process began in 1772). In the twentieth century, the destruction of the urban fabric was caused by the fronts of the two world wars that swept across the country. This was combined with the toilsome reconstruction that came afterwards. In addition, it should be remembered that, as a result of the peace treaties that ended the Second World War, Poland lost over half of its territory to the Soviet Union [51], gaining a portion of highly urbanised German lands-in Silesia, Pomerania and Masuria. These territories were heavily damaged at the start of the war, but after its conclusion they became (and often reprised their role as) Poland's western and northern provinces [52]. Understanding these historical processes and their associated economic and social changes explains why uneven industrialisation exerted different types of impacts on the urban layouts of contemporary Polish cities. The totalitarian communist regime that governed the country up to 1989 (dependent on the USSR similarly as in the remainder of Central Europe) promoted industry at the cost of other branches of the economy. Due to this fact, the liquidation of large industrial plants in cities and the associated economic and spatial changes in Poland [53] started to take place during the final years of the twentieth century and continue to this day [54]. In Western Europe, these changes began earlier, in the 1980s [55].

As stipulated by the principles of sustainable development, confirmed both in urban planning manifestoes [56] and numerous international [57], national and local acts of law [58], reports [59] and planning documents, and stated in the findings of academic studies, the reuse of brownfields and their reincorporation into urban structures is desirable [60]. It appears to limit the negative consequences of exurbanisation. It can lead to the renewal of districts located closer to city centres and an inwards-oriented urban development as opposed to urban sprawl. Preceded by numerous analyses and multidisciplinary studies, supported by elaborate and sophisticated legal and planning systems that appear to guard the public interest and aid the development of cities and regions, European cases of successful post-industrial area revitalisation processes [61] show a broad range of possibilities [62]. 


\subsection{Brownfields in Polish Cities_Problems with Spatial Development}

Successful cases of revitalising urban brownfields in Western European countries as discussed in the literature [63-65] can in many cases act as models for strategies for transforming similar areas in Poland $[66,67]$. Especially as their careful analysis could aid in avoiding numerous mistakes or unneeded procedures that would only extend their transformation. Therefore, apart from transforming the physical urban structure, they could, based on interdisciplinary studies, also contribute to modifying the legal system and the manner of formulating planning documentation provisions [68].

Sometimes this is actually the case, and Gdańsk-based projects can act as model examples for similar projects in Poland, especially the still ongoing revitalisation of postshipyard areas as a part of the 'Young City' and the almost-complete measures at Wyspa Spichrzów [69]. Urban renewal was preceded there by many years of studies, workshops and reports prepared with the participation of urbanists and planners from the Faculty of Architecture of the Gdańsk University of Technology (under the supervision of M. Kochanowski and later P. Lorens). They were associated with public participation and were conducted with a great number of stakeholders, which enabled the best possible preparation of similar projects under Polish legal conditions. In the case of Gdańsk, the measures and preparation of research and planning documents, together with multi-alternative studies, urban and architectural design competitions and even masterly workshops conducted by world-famous architects, were undertaken long before the passing of the Revitalisation Act in Poland in 2015. The Act stresses social and economic matters and greater participation of all stakeholders in decision-making via the legal strengthening of public participation measures [57]. Despite the final outcome often being different than stipulated in the ideal model assumptions from reports from many years ago, they have made their mark on the city's current planning documents. Over a decade later, the measures taken to transform Gdańsk's central, post-industrial zone have their own dedicated and perfect academic documentation [70-72].

However, despite the new Act being in force for five years, in light of the crisis of Poland's spatial planning system that shall be briefly discussed later, revitalisation measures targeting areas abandoned by industry and the military and the need to provide them with infrastructure leave much to be desired. This is partly to blame on legal imperfections and the pioneering nature of the relevant solutions. For over a decade, considerable focus was placed primarily on aesthetic and construction-related aspects [73], which led and still leads to the gentrification of areas subjected to revitalisation [74]. Revitalisation has often been performed as if played by ear, often based on good foreign models (which cannot always be directly transplanted to a different spatial and socioeconomic setting), and sometimes without paying them any mind [75]. However, the outcome of brownfield transformation projects in Poland is primarily the result of low social awareness among decision-makers, real estate developers and future buyers of buildings and spaces created through the process in question [76]. The problem applies to the principles of shaping spatial structures in cities. This can also be associated with a very low level of architectural and urban education in the country at the primary- and high-school level [77]. Likewise, the country's liberal brand of capitalism is also to blame, as it strives to maximise profits with disregard for social and spatial costs of its decisions and is an understandable and natural social reaction to decades of communist rule [27].

In the country's largest cities and metropolises (Warsaw, Cracow, the Gdańsk-SopotGdynia Tri-city, Wrocław, Poznań, Łódź or the Upper Silesia-Zagłębie Metropolis that was established in 2018 and consists of 41 cities and communities in Upper Silesia), there has been increasing development pressure on areas freed up by industry and on the infrastructure necessary for them to operate. This increase has had a different pace in different areas [78]. Especially that once-peripheral areas have currently found themselves in city centres, such as the areas of 'Młode Miasto', Wyspa Spichrzów, Dolny Wrzeszcz and Garnizon in Gdańsk, or Zabłocie, Podgórze and Grzegórzki in Cracow, Breweries in Cracow and Warsaw, Praski Port in Warsaw. The same has happened with numerous 
post-factory areas in Łódź [79], cities of the Upper Silesia-Zagłębie Metropolis and many others [40,80-83].

After 2003, Poland has entered into a crisis of spatial planning as previously enforced spatial development plans (acts of local law) were voided by a new Spatial Planning and Development Act [57]. This was combined with the obligation placed on municipalities to enact new spatial development conditions and directions studies. These studies did not have the status of local law and were merely intended as guidelines, to provide the basis for drafting new plans. Many municipal governments-including Poland's largest cities-have not fulfilled this obligation to date (October 2020). Some of them have done so only partially, enacting local plans only for fragments of their territories. This situation has led to land speculation that is difficult to control and the widespread practice of using legal loopholes during the issuing of construction permits. They are based on administrative decisions that are permitted in situations where there is no development plan in place for a given area, despite the fact that legislation that has been amended several times after 1989 [84].

This has also contributed to an excessive densification of new, functionally varied development (primarily commercial, office and residential) on brownfields obtained for real estate projects, primarily those located in city centres. This densification is typically motivated solely by short-term profit instead of correct relationships between urban structures and spatial order. It typically takes place without ensuring proper transportation, educational, cultural or blue-green infrastructure. This problem, apart from periodically generating media outrage and public protests, has also become the subject of numerous academic studies in Poland $[85,86]$.

The irregularities and flaws of this form of shaping the city are particularly visible in multi-family housing complexes of varying size, which are primarily built by real estate development companies that offer apartments for sale [87]. Housing shortage, caused by years of underfunding and crises during the period of communist rule, continues to be a problem in Poland, as indicated by a report on the housing situation from March 2020 [88]. The report points to a state-wide apartment shortage of around 650 thousand units. Demographic change, as well as treating apartments and houses as a form of capital investment, have led to an overproduction of expensive, privately-owned apartments, built primarily by large real estate development companies and non-institutional developers [89].

The desire to maximise sales profits caused housing environment quality in complexes built in the years 1999-2020 to typically leave much to be desired [90]—even despite the observably better visual attractiveness of their architecture in most cases, although this cannot always be said of apartment functionality. However, it appears that the market for privately-owned housing associated with real estate development company projects is slowly beginning to exhaust itself-particularly in large cities, where real estate prices have been increasing along with the number of completed projects for over a decade. Perhaps the current crisis associated with the COVID-19 pandemic and lower demand for dwellings and office spaces for rent, caused by numerous associated factors [91] is one of the reasons behind this. For comparison, the number of social or municipally owned housing handed over for use has been declining and in 2019 amounted to only $2.2 \%$ of all construction projects [88].

\subsection{Post-Industrial Areas-Overview and Specificity of Cracow's Downtown Area}

The beginnings of Cracow date back to the end of the ninth and the beginning of the tenth century and are associated with a fortified gord on Wawel Hill (which is now the site of Poland's largest castle and cathedral complex). It towered above a stretch of swampland in the bend of Poland's largest river-the Vistula, which has been a major circulatory and commercial thoroughfare for over 900 years, ensuring prosperity and economic development to cities and settlements erected along its course [92]. Cracow is currently Poland's second-largest city (with around 769,000 residents in 2020) and a former state capital (between the eleventh and sixteenth century). The city is of immense 
symbolic and cultural significance to Polish national identity, a city of culture and science that attracts thousands of students and researchers and millions of tourists and pilgrims. In 1978, the urban layout of Cracow's Old Town (from 1257) together with the suburbs of Stradom and Kazimierz (from 1335), as well as Wawel Hill, was placed on the UNESCO World Heritage List. In 2010, a large portion of the city centre, within the so-called second ring road [93], which corresponds to the size of the city's urban area towards the end of the nineteenth century [94], was also added to the UNESCO List as a buffer zone.

However, like every city, Cracow's history features periods of prosperity and decline. Towards the end of the eighteenth century, after the third partition of Poland in 1795, after suffering damage in almost two centuries of wars and epidemics and a population decrease to around 10,000 [37], Cracow found itself under Austrian rule. From among the Polish cities incorporated into Austria, it was Lviv (currently in Ukraine) that developed much more dynamically and became the capital of Galicia, a new province created by the occupying power. With a peripheral location, close to a new border with Prussia and Russia that had been created after the partition of Poland among the European powers, Cracow became a distant backwater to the Austrian Empire, without major significance to the state's economic development. The rise and fall of Napoleon I and the associated geopolitical events, primarily the establishment of the Cracow Republic facade state in 1815 , enabled demographic growth. In 1843 , the city had a population of 43,000 , with areas located on the southern shore of the Vistula-including the district of Podgórze-not counted, as formally Austrian territory. Due to its location at the border between three major powers-Russia, Austria and Prussia-the city gained a certain stabilisation and moderate economic development, primarily based on trade.

The development of industry in Cracow was largely confined to milling and alcohol distillation-no attempts at establishing a modern manufacturing industry were recorded at the time, although it did start to develop in other areas of contemporary Poland (Warsaw, Wrocław, cities of Upper Silesia or Poznań). The reincorporation of Cracow into Austria in 1846 did not change the situation, especially as the city's development was limited and subjected to military regulations. In the middle of the nineteenth century, Cracow was labelled a fortress city (Festung Krakau) and as such (with a later loosening of rigorous regulations) survived until the First World War and the end of the Austro-Hungarian monarchy [38]. It was the outline of the fortress's core (noyau), the first of three liens of defence, that determined Cracow's spatial development up to the first years of the twentieth century [95] and it is this area that was inscribed onto the UNESCO World Heritage List as a buffer zone (Figure 1). However, in the second half of the nineteenth century (following the Austrian act on industrialisation from December 1859), factories appeared in the city. They served not only its needs, but also the Austrian internal market and the production of export goods, along with increasingly modern industrial plants necessary to service the city and its infrastructure, such as waterworks, a gas plant and several power plants [37]. 




Figure 1. Centre of Cracow_UNESCO protected area from 1978 (marked with orange line) and its extension—-the buffer zone from 2010 (marked with green line), source: http:/ / whc.unesco.org/en/list/29/multiple=1\&unique_number=1739 (public domain). 
The first modern planning document-the Greater Cracow Regulation Plan-was drafted on the basis of a winning conceptual proposal (Figure 2) selected in a competition organised by the city in 1910. It sanctioned and regulated the placement of industrial areas in the eastern and southern part of the city, primarily in the contemporary districts of Wesoła, Grzegórzki, Kazimierz, Podgórze and Zabłocie [41]. Due to the previously mentioned military constraints, newly erected industrial plants found themselves in the immediate vicinity of the historic city centre. Some of these plants survived the interwar period and the Second World War and even continued to develop during the People's Republic of Poland (until 1989). Of these, some continue operating today, and the traces of others are a post-industrial heritage that is important to the city.

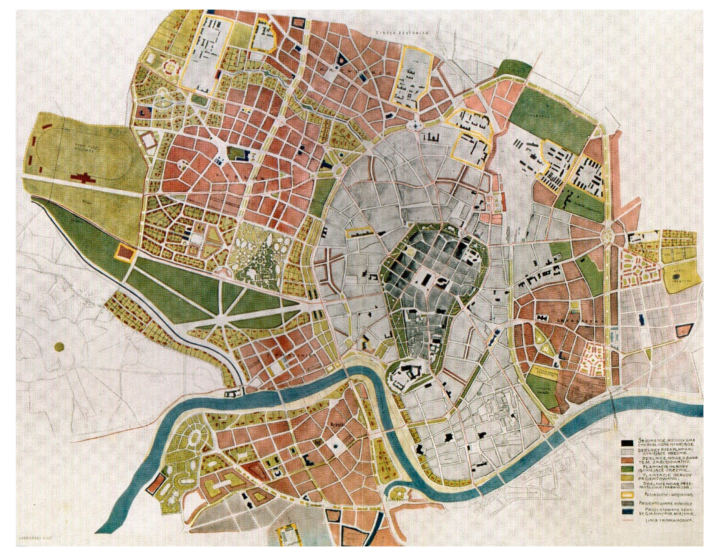

Figure 2. The Greater Cracow Regulation Plan—the winning competition entry by: Józef Czajkowski, Władysław Ekielski, Tadeusz Stryjeński, Ludwik Wojtyczko and Kazimierz Wyczyński, 1910, The creation of the urban form, extended beyond former fortifications of the inner city (everything that is marked differently than dark and light grey). The proposed layout, although never completed in that form, has been in many points repeated by the following urban plans of the city. source: reproduction in the collection of the Chair of Urbanism and City Structure Architecture of the CUT FA, photo by M. Nowak.

In the years 1945-1989, similarly as in other cities in the country, Cracow again saw an intensive wave of industrialisation, with several dozen factories and industrial plants of varying size and significance distributed across the entire city. They were located primarily within the territory outlined in the pre-war plans of the city-to the east of the centre and along the Vistula, as a suitable waterway. The infrastructure serving industry was extended as well-primarily in the form of roads and railways. These projects and their inconvenience over decades of operation have affected their immediate surroundings, the cityscape and the environment in various ways [96].

The peak manifestation of Cracow's industrialisation, as well as a form of political manifesto by the new, pro-Soviet government, was the construction of an enormous metallurgy plant in the years 1949-1954-the Vladimir Lenin Steelworks (now owned by ArcelorMittal Poland, which announced in October 2020 that it will cease to produce steel). The factory was established to the east of the existing urban structure of the city, on the northern shore of the Vistula. This metallurgy plant became the largest industrial complex in the city and one of the largest in the country. It was accompanied by the foundation of a Socialist Realist ideal city-Nowa Huta-on the territory of the existing villages of Mogiła, Bieńczyce and Krzesławice. These areas were incorporated into Cracow already in 1951, and over time became increasingly well-connected with it in physical terms, via its development structure, transportation system and a layout of green recreational areas that are now being increasingly damaged by new development projects [97]. This evolution can be recreated based on historical photographs, maps and planning documents [39] (Figure 3). 


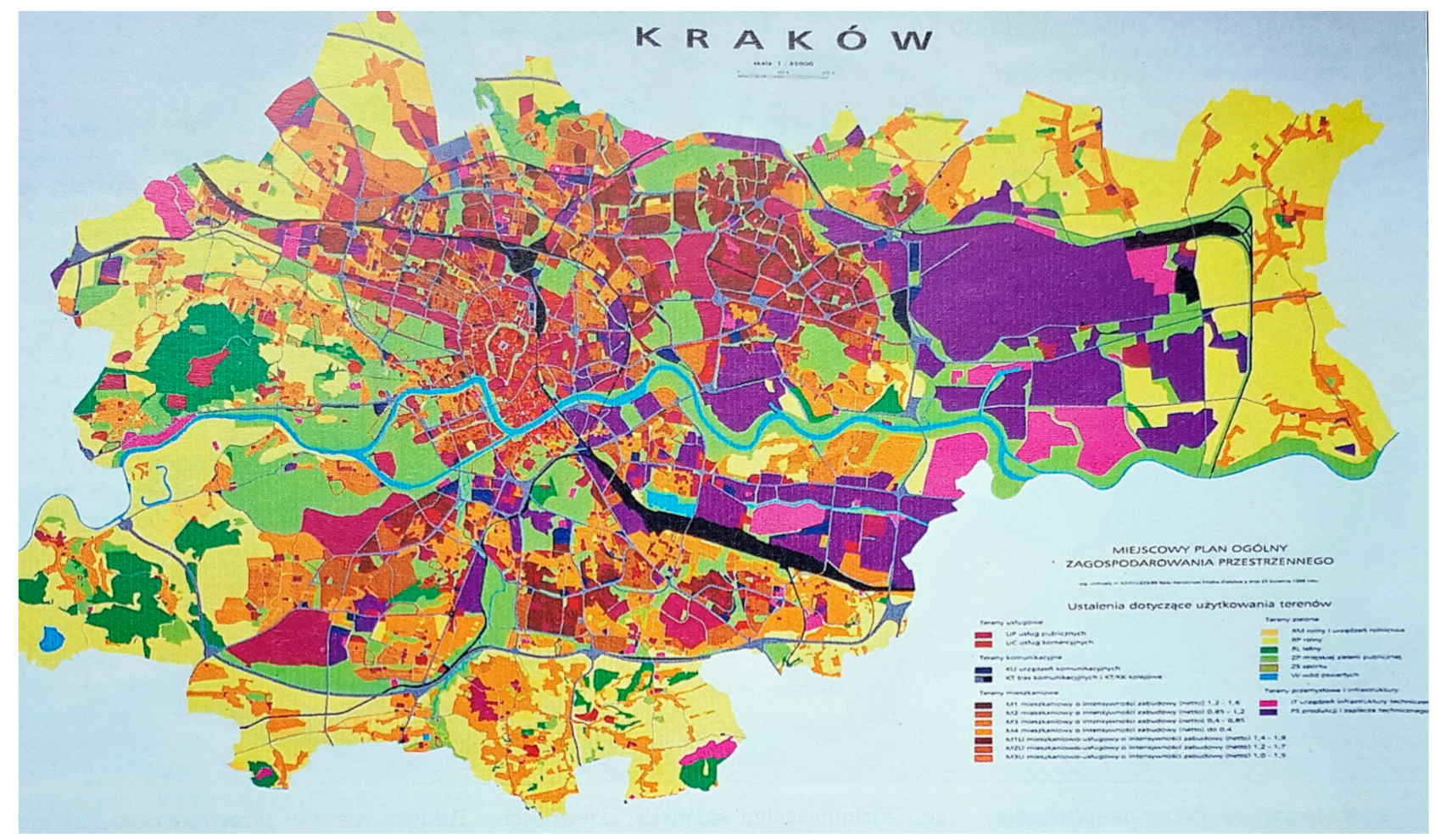

Figure 3. Drawing of the Local General Spatial Development Plan of the City of Cracow, drafted by a team under the supervision of Z. Ziobrowski in the years 1988-1994, shows a significant concentration of industrial and infrastructural uses (violet, pink) and their supporting railway infrastructure (black) in the eastern part of the city (around 70\% of build-up areas) in relation to the western part of the city (around $12 \%$ of build-up areas). However, it is visible that the plan maintained the historically grounded industrial and infrastructural use even in central areas, particularly located near the Vistula River and along railway lines. This plan was in effect up to 2003. Source: reproduction in the collection of the Chair of Urbanism and City Structure Architecture of the CUT FA, photo by M. Nowak.

\section{Results}

\subsection{Selected Cracow-Based Cases of Contemporary Housing Projects in City-Centre Revitalised Brownfields}

The detailed study presented in this paper concerns cases of housing and mixeduse housing and service projects built in the years 2000-2020 on sites formerly occupied by industrial and infrastructural plants and storage complexes. They are located in the city centre of Cracow and as such primarily within and in the immediate vicinity of the UNESCO buffer zone and even inside the strict conservation zone established in 1978 . Not all these areas were identified in applicable planning documents as intended for revitalisation (Figure 4). However, their transformation can be seen as offering a new spatial quality in zones that were excluded and inaccessible to residents for many years. Sometimes, it even forms a desirable continuation of generally accessible urban fabric, with a particular focus on the system of green public spaces. 




KORYTARZE ZIELONE A PROJEKTY REWITALIZACJI 2030/50


Figure 4. Areas planned for revitalisation and the network of the city's main green corridors—vision 2030-50; post-industrial areas covered by revitalisation plans in 2017 (black grid) and key to revitalisation (violet grid); by M. Gyurkovich, A. Szarata, Z. Zuziak and team, drafted by A. Derlatka 2017, source: [58], available by the courtesy of the Spatial Planning Bureau of the Office of the City of Cracow.

Citywide blue-green infrastructure is crucial for creating a healthy housing environment. In Cracow, it is primarily formed by a network of city parks and riverside green areas (called 'river parks' in planning documents), both landscaped and left in their natural state. They are supplemented by large greenery complexes-those of Las Wolski and the protected areas of several landscape parks in the western part of the city and large green areas, typically flood plains or farmland, in the northern and eastern edges of the city (some, including the Nowa Huta Meadows, labelled as ecological use or Natura 2000 areas). This system, although it is supplemented by greenery that accompanies the road and path network, is not continuous. The most important citywide connector is the Vistula river park [98], as the river flows through the entire city from west to east. Many areas located along the Vistula possess unique landscape, recreational or ecological assets (Figure 5). 


\section{KRAKÓW PLANSZANR 21 - SIEĆ STABILNOŚCI EKOLOGICZNEJ KRAKOWA (SSEK)} BOŻENA DEGÓRSKA

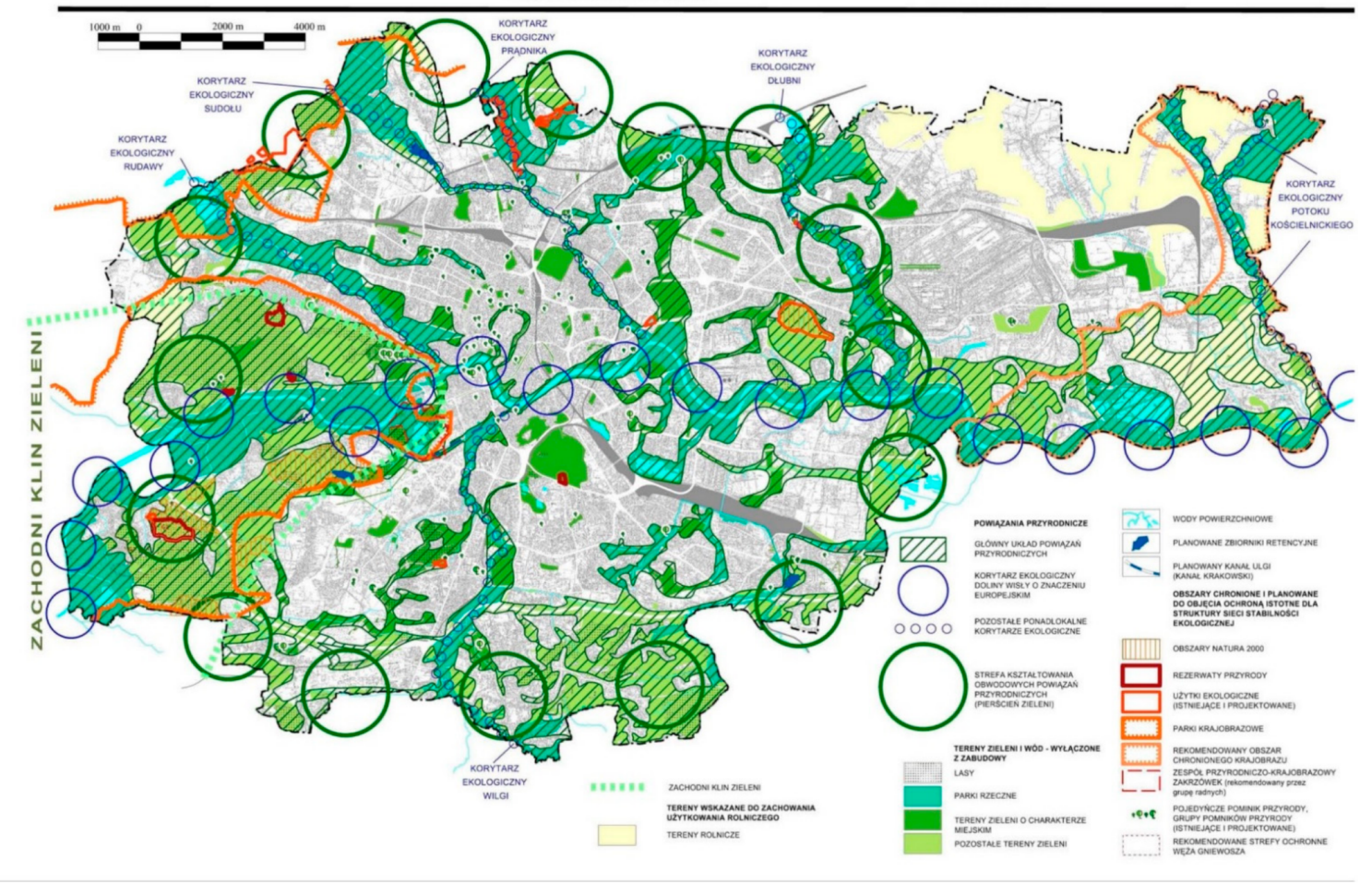

Figure 5. Cracow Ecological Stability Network—Sieć Stabilności Ekologicznej Krakowa (SSEK), by B. Degórska, source: [17]. Rivers and its surroundings marked cyan, forests -dark green, lawns-light green. Different forms of protected landscapes marked with red, pink and orange outlines. The ecological corridor of Vistula River Valley (crucial in the scale of entire Europe) marked with large dark-blue circles, smaller blue circles along the river valleys shows the ecological corridors of supra-local importance. Dark-green circles shows the range of "green ring" around the city.

Four completed housing projects that were built in post-industrial central plots and possess linkages with the city's blue-green ecological system were selected for further in-depth analysis. This was the most important criterion for case selection, apart from all of them having a dominant housing function. Three of the projects were built as singular, large endeavours, adaptations or as a result of remodelling small industrial plant buildings: Browar Lubicz at Lubicz Street, Wawrzyńca 21 in the Kazimierz district and a mixed-use service and residential building at Nadwiślańska Street, in the historical area of Podgórze. The study also covered two large industrial and storage areas that are currently being adapted into exclusive housing areas. These areas are located in the immediate vicinity of the Vistula River Valley -in the districts of Grzegórzki and Zabłocie, east of the historic city core that features the most precious elements of urban and architectural heritage (Scheme 1). These areas functioned almost up to the start of the twenty-first century. They comprised numerous manufacturing plants and institutions that were founded between the middle of the nineteenth century and 1989, and their multi-stage remodelling is still ongoing, with different real estate developers participating (Figure 6). 


\section{SURFACE OF STUDY AREAS ( in hectars)}

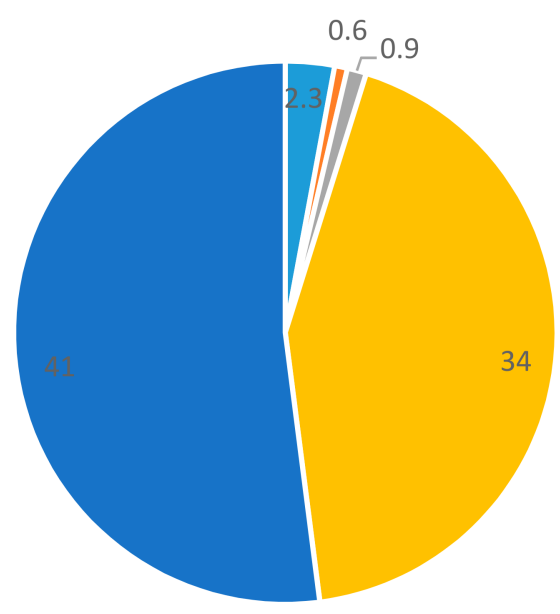

- Browar Lubicz - Wawrzyńca 21 - Nadwiślańska - Grzegórzki - Zabłocie

Scheme 1. The comparison of the surface of the areas under study.

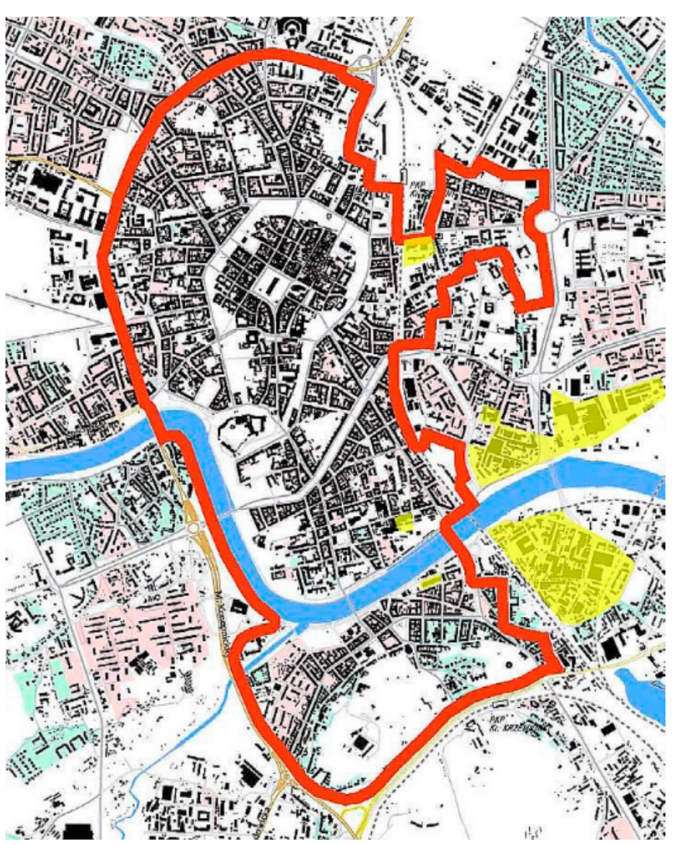

Figure 6. City centre of Cracow-territory covered by the Local Old Town Revitalisation Plan from 2008 (red), the present-day Historical Urban Complex, Monument to History (https:/ /msip.um. krakow.pl). The areas discussed in the paper are shown in yellow-on some sites one can still see the industrial structure present at the time—based on: [99] https:/ / rewitalizacja.krakow.pl/.

\subsubsection{Small Interventions within the Historic Urban Tissue of Cracow}

The Browar Lubicz project is one of the first and most successful examples of revitalising post-industrial areas in Cracow's historic urban centre. The small brewery, which belonged to the Goetz family of Galician market potentates, was built in 1840 on the border of the suburbs of Wesoła and Lubicz [37] and was afterwards successively extended and modernised. It operated up to the early 1990s. The site is located near a railway track, in the immediate vicinity of the Main Train Station, a Jesuit monastery and a complex of clinical 
hospitals that expanded throughout the entirety of the twentieth century [100]. The most valuable buildings were placed in the municipal register of monuments in 1995 [101], while many later buildings, primarily from the 1960s and 70s (Figure 7), of low architectural and aesthetic value, were demolished. Changes in designers and developers, as well as precise and restrictive local development plan provisions (that only covered the project site) led to the preparation of a series of highly similar design proposals. Ultimately, the design was prepared by the Cracow-based MOFO architectural firm [102].

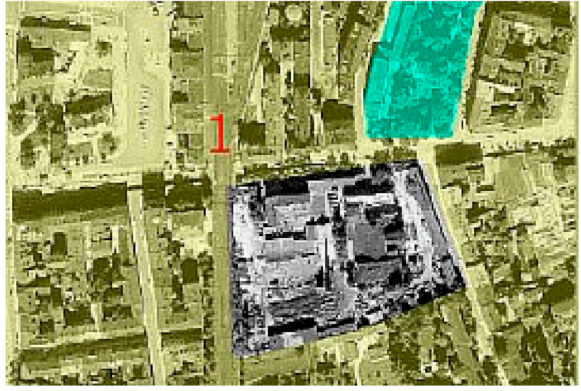

(a)

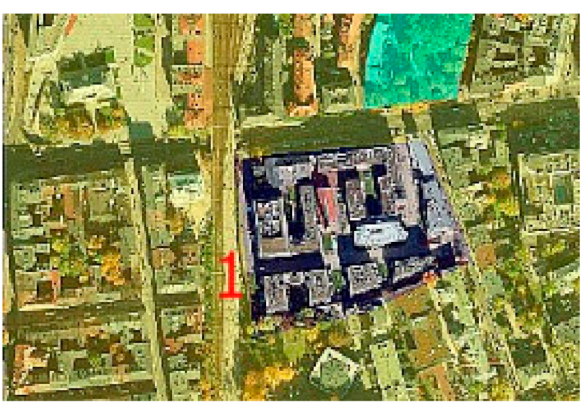

(b)

Figure 7. Comparison of orthophotomaps of the selected fragment of Cracow's urban fabric under study (1. Browar Lubicz) from 1970 (a) and 2019 (b) against public greenery (cyan). There is an observable change in urban fabric typology and density. Based on aerial photography from https://msip.krakow.pl.

A housing and office complex was built at the site of the former production plant, and the former gates to the brewery are now open, inviting pedestrians into its interior. These openings are a continuation of locally significant compositional axes, primarily the longer axis of Park Strzelecki (Marksmen's Park). 'The new massings were combined with existing ones in a manner that references the layout of the brewery's historic development' [103]. A tall, slender 'factory' brick smokestack continues to act as the complex's dominant element, which, together with a restored boiler building, became the centre of a small recreational space. The architecture of the complex's housing buildings primarily features brick and steel, as well as wood, as finishing materials, blending new facades with the restored walls of historic sections, adapted to new functions-primarily commercial ones (offices, restaurant, shops). The brewery's old equipment further enhances the attractiveness of the complex's partially green social spaces. The proximity of the historic centre and the city's main transportation node, along with numerous public institutions and corporation offices, has contributed to the commercial success of the project, whose buildings were built to a very high finishing standard (Figure 8).

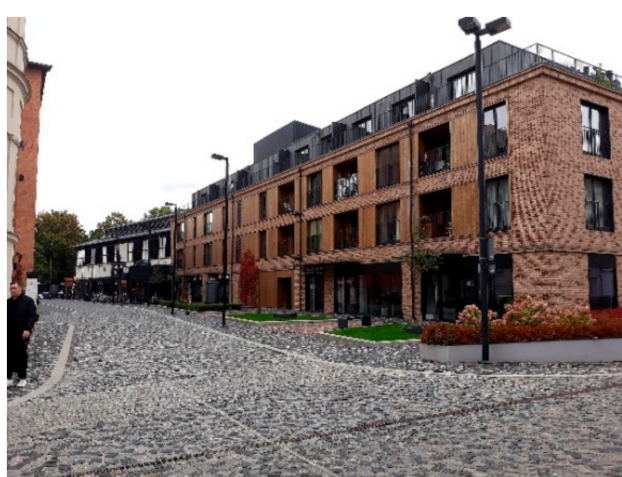

(a)

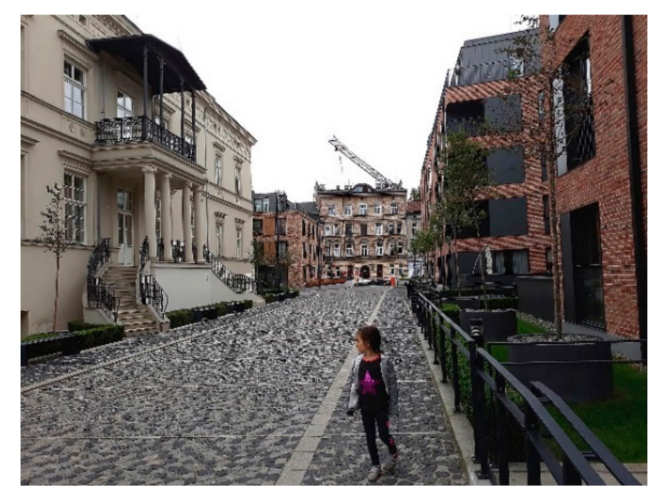

(b)



(c)

Figure 8. Browar Lubicz housing complex-as seen in 2019. Photo by M.Gyurkovich (a) view from the complex towards the park; (b) internal street with the former palace of the brewery owner on the left; (c) chiminey left as a symbol. 
The course of Wawrzyńca Street is a trace of the outline of Kazimierz's medieval city walls. It is here that, on previously undeveloped land, the first infrastructural plants that provided amenities to the city began to be built in the second half of the nineteenth century: a gas plant, a power plant and a tram terminus [37]. Some of the historic buildings, including 'gasometres', disappeared, while others, which remained in the hands of energy and gas companies, act as administrative and office buildings (Figure 9). The half-timbered buildings of the terminus now house the Municipal Engineering Museum and gastronomic establishments. Other historic buildings were taken over by private real estate developers. This was the case for one of the buildings that once belonged to the municipal power plant-at 21 Wawrzyńca Street. Detailed architectural and conservatorial documentation and a series of conceptual design alternatives led to the construction of the Wawrzyńca 21 apartment complex. The complex, built to a design by architects from B2 Studio, consists of two city blocks (Figure 10a,b). In the frontal, northern block, historic buildings were extended and connected to new sections, whose neutral detail, maintained in a 'postindustrial' aesthetic, highlights the remains of former structures (Figure 11). The southern block, in the shape of the letter U, opens towards the Vistula, the green Krzemionki Hill on the river's southern bank and, in its immediate vicinity, the site of the former gasometres, commemorated in the form of a small green square. This complex, due to its ownership situation, does not have direct linkages (apart from visual ones) with the green square or the riverside boulevards, which are separated from it by a street. However, the development's central location, unique views and a particular attention to the post-industrial place-based heritage remain its key assets.

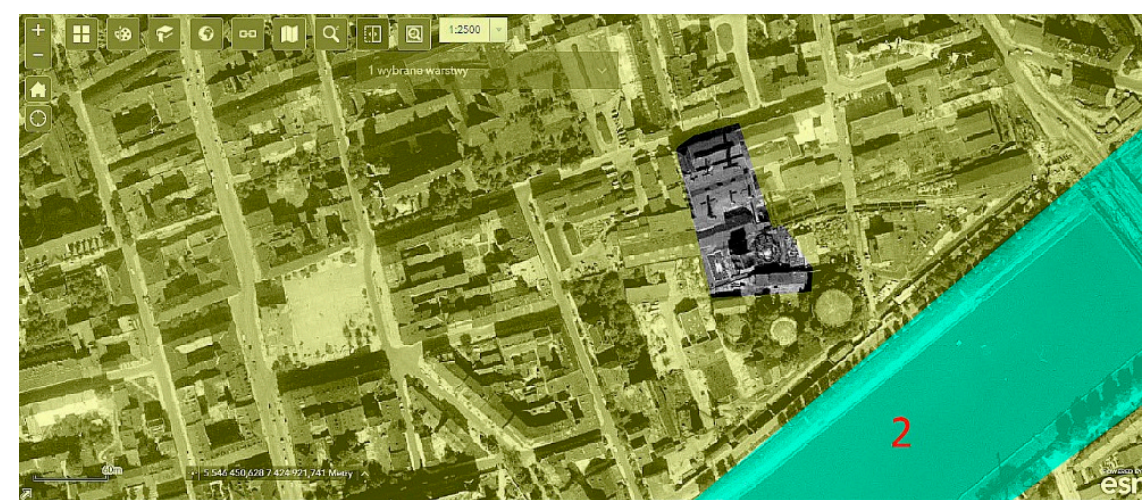

(a)



(b)

Figure 9. Comparison of orthophotomaps of the selected fragment of Cracow's urban fabric under study (2. Wawrzyńca 21) from 1970 (a) and 2019 (b) against public greenery (cyan). There is a visible change in urban fabric typology and density-based on aerial photography from: https: //msip.krakow.pl. 


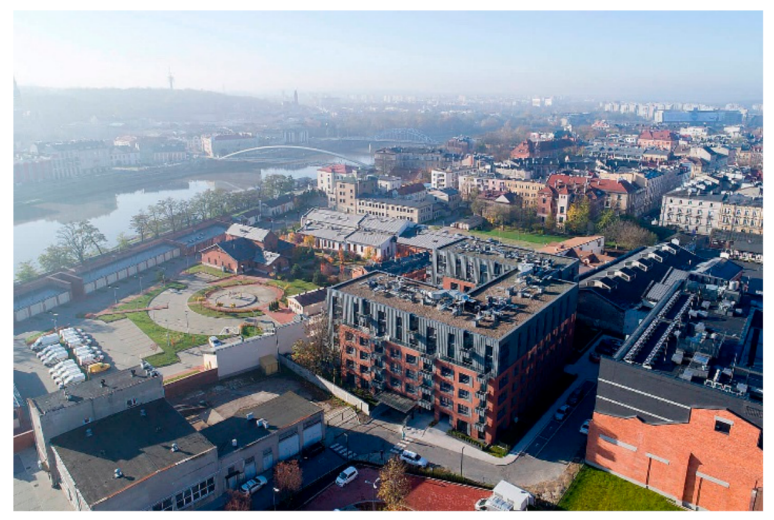

(a)

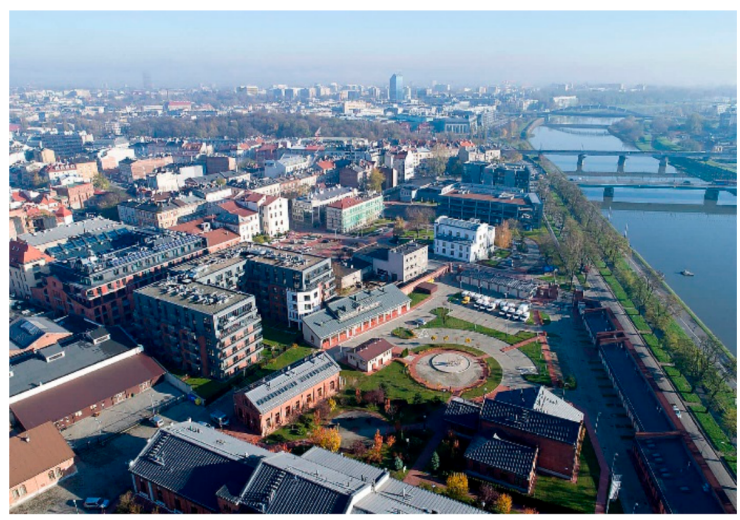

(b)

Figure 10. Exclusive housing complex on the site of a former power plant and gas plant in Kazimierz-Wawrzyńca 21—as seen in 2020-view towards the south-west (a) and towards the east (b); Photo by P. Krajewski, courtesy of J. Białasik, source: http://b2studio.com.pl/projekt/apartamenty-wawrzynca-21/.

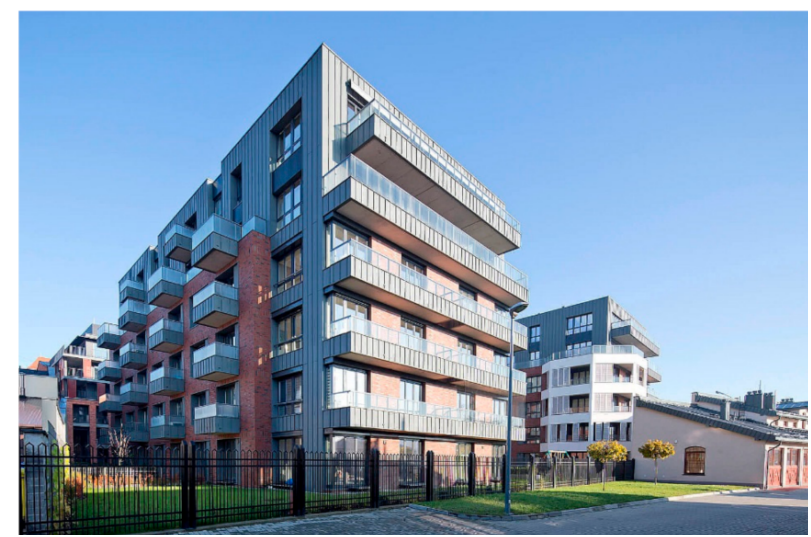

Figure 11. Details and materials inspired by the post-industrial genius loci-Wawrzyńca 21-as seen in 2020; Photo by P. Krajewski, courtesy of J. Białasik, source: http:/ /b2studio.com.pl/projekt/ apartamenty-wawrzynca-21/.

The Nadwiślańska Apartments complex of residential and service buildings in the district of Podgórze, located in a narrow, elongated city block between Nadwiślańska, Piwna and Krakusa streets, was built in the years 2011-2014 almost at the Vistula's shore. This area is located in the vicinity of Podgórze's former nineteenth-century power plant, built near a railway line that ran along the river. The power plant was redeveloped and adapted in the years 2006-2014 into a cultural facility—one of the city's most iconic buildings, the Cricoteka [92].

In the nineteenth century, the plot in question was occupied by small storage buildings and industrial plants. After the Second World War, a complex of buildings of the Vistula textile factory was built here, together with a tall and characterless sewing hall (Figure 12a). After the complete relocation of the plant outside of Cracow in the beginning of this century (to the town of Myślenice, located $35 \mathrm{~km}$ away), the plot was sold, and the buildings were demolished. The new project continues or perhaps even goes beyond the scale of the former sewing hall, referencing a nearby hotel from the 1990s and an office building at neighbouring Bohaterów Getta Square. 


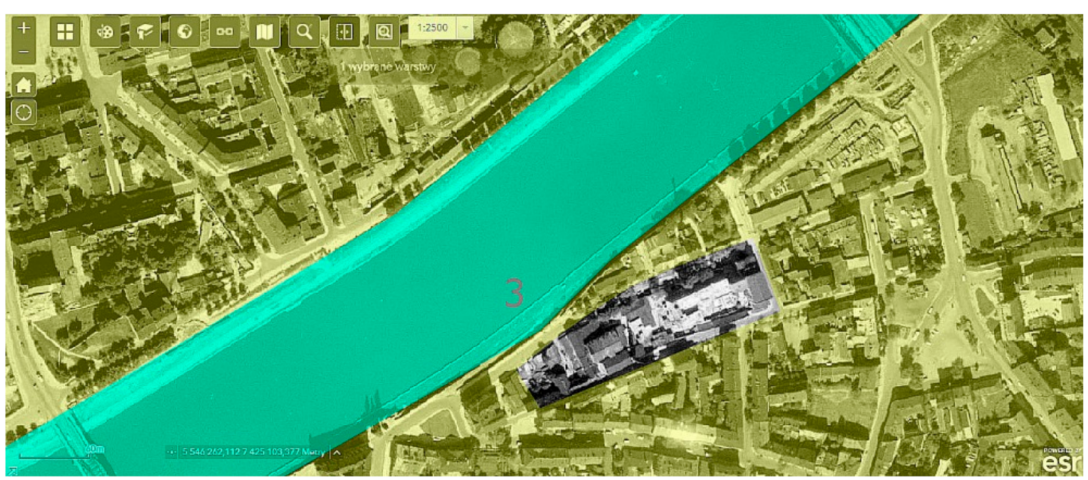

(a)



(b)

Figure 12. Comparison of orthophotomaps of the selected fragment of Cracow's urban fabric under study (3. Nadwiślańska Apts.) from 1970 (a) and 2019 (b) against public greenery (cyan). There is a visible change in the urban fabric's typology and density, based on aerial photography from: https://msip.krakow.pl.

It is one of the tallest buildings in Old Podgórze, many times taller than the nearby historical development and even the later urban infills built between the 1960s and 1990s (Figure 12b). Due to the sculptural form of its massing, which creates an illusion of a division into a sequence of several townhouses, the mass is not excessively overwhelming, and the scale appears adequate to building the frontage of a river valley in the city centre (Figure 13).

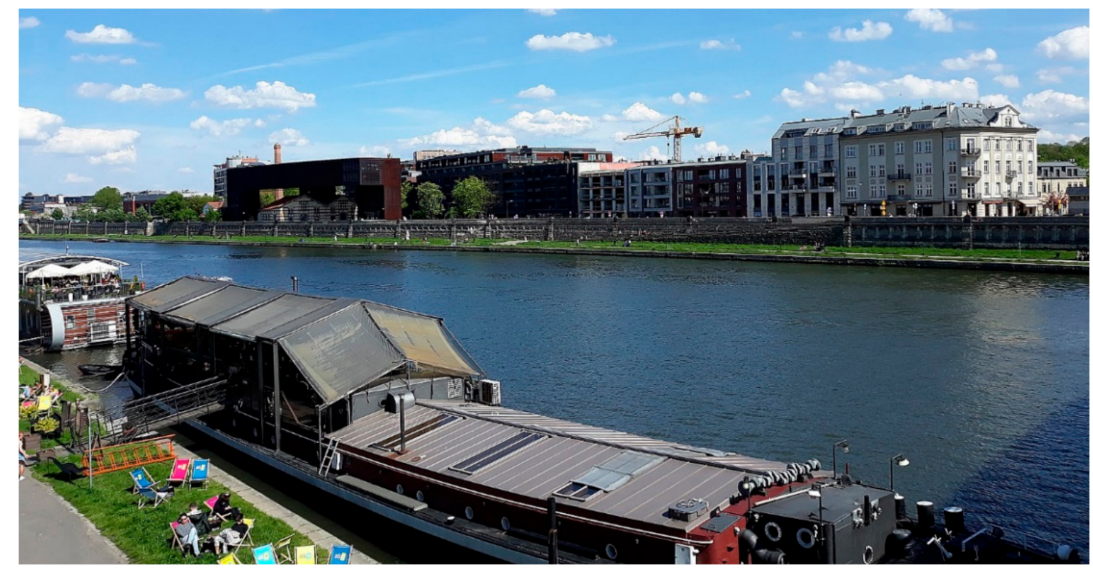

Figure 13. The Vistula River boulevards as seen from a footbridge, with Cricoteka and the project under study (Nadwiślańska Apartments) in the background-as seen in 2019. Photo by M.Gyurkovich.

Primarily featuring dark, industrial brick in several shades of colour, along with large, glazed surfaces and steel elements, the project by Saran Architekci is a neutral backdrop for the unique architectural form of the Cricoteka (Figure 14a). Service premises on the 
ground floor and the presence of new residents, mostly young professionals, have made this once-excluded area a living fragment of Podgórze's urban fabric, which is undergoing gentrification (Figure 14b). Apartments in the building offer unique views of the Vistula River Valley's panorama, the historic area of Cracow towards the north, and the green strip of Krzemionki Hill, which compositionally encloses from the south the historic urban layout of Cracow, developed for 9 centuries along the north-south axis [104].



(a)

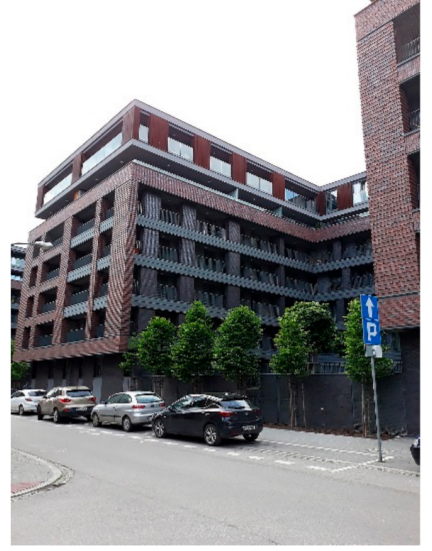

(b)

Figure 14. Nadwiślańska residential and service complex- view from across the river (a) and from the south- opposite side (b). Photo by authors.

4.1.2. Transformation of Large Post-Industrial Areas in the City Centre near the Vistula River

The Grzegórzki district, located on the left bank of the Vistula, to the east of the historic city centre, together with Zabłocie, located on the opposite side of the river, underwent rapid industrial development at the turn of the twentieth century. Since the Middle Ages, the river had been the major route for transporting goods [96], and the construction of railway lines eastwards from Cracow's centre enabled the development of additional factories. The combination of newly erected plants and riverside storage areas with a system of railway tracks running along shores and connected with train stations enabled the plants to survive and develop at the site. They operated up to the end of the People's Republic of Poland in 1989. It was then that the global economic situation began to affect Poland's economy and thus the spatial form of Polish cities.

Unprofitable plants that typically occupied attractive land with good spatial linkages in city centres became increasingly attractive to real estate developers. These changes were noted by city planners and decision-makers, contributing to the planning and construction of significant infrastructural projects in this area. The most important ones included a new river crossing-Kotlarski Bridge (competition 1999; construction 2001). Along with the modernisation and extension of streets that led to it, it linked Grzegórzki and Zabłocie (by car, tram, bus, on foot and bicycle). It also led to the closing of the loop of the second ringroad of the city, which roughly corresponded to the line of the core of nineteenth-century Austrian fortifications [38]. The project clearly sped up the revitalisation of Zabłocie. It began several years earlier on the 'better' shore, in Grzegórzki, closer to the city centre.

The fall of large industrial plants in Grzegórzki towards the end of the 1980s, which affected, among others, the Zieleniewscy Machine Industry Plant (which was the largest factory in Cracow up to the 1940s) or the relocation of others-the municipal slaughterhouse or the neighbouring chocolate factory (Figure 15a) - freed up large areas for new development. In the western part of the district, on the site of the former slaughterhouse, the Galeria Kazimierz commercial ad service centre was built in the years 2004-2005 [105]. It was soon surrounded by office and hotel buildings and later several smaller housing complexes (built in stages up to 2020). Apart from fragments of the road layout and three 
heritage-listed buildings of the former slaughterhouse (from 1871), the post-industrial heritage of the site is completely imperceptible. This is felt even more in the eastern part of the district, outside of Kotlarski Bridge, where no local spatial development plan was enacted between 2003 and October 2020 (Figure 15b).



(a)

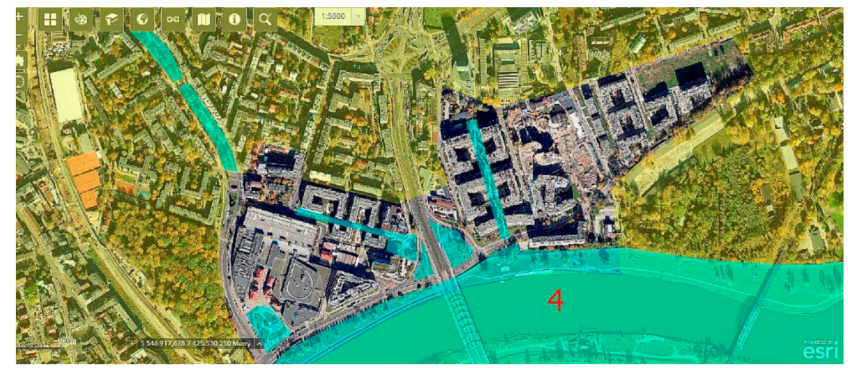

(b)

Figure 15. Comparison of orthophotomaps of the selected fragment of Cracow's urban fabric under study (4. Grzegórzki) from 1970 (a) and 2019 (b) against public greenery (cyan). There is a visible change in the urban fabric's typology and density, based on aerial photography from: https:/ / msip.krakow.pl.

These areas are converted into housing estates without proper service and educational infrastructure. In these departments, they are based on existing neighbouring institutions from the 1970s and 1980s. Sometimes new educational functions appear as secondary adaptations of the ground floors of existing or even newly designed buildings. The second ones typically feature a certain number of commercial premises for rent. Nearly all buildings and infrastructural elements that signified the district's post-industrial heritage have been demolished (including two factory halls which continue to be listed in the municipal monuments register!). The only building that is under protection is a Socialist Realist cinema theatre (currently a musical theatre). In architectural terms, the buildings and complexes built in this part of the city are characterised by high diversity of styles and sizes, but also by formal attractiveness. However, their architecture does not reference local tradition and could be built in any place in the world looking equally as attractive (Figure 16a,b). Some complexes (like Wiślane Tarasy I) could be characterised by attention to and a quality of the housing environment, along with pleasantly composed semi-private and public greenery. They supplement the municipal system of blue-green infrastructure (Figure 17a,b). 


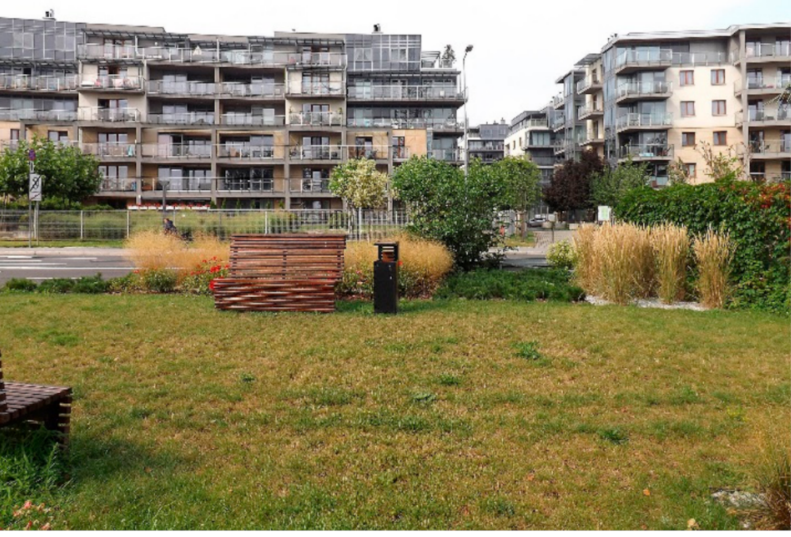

(a)

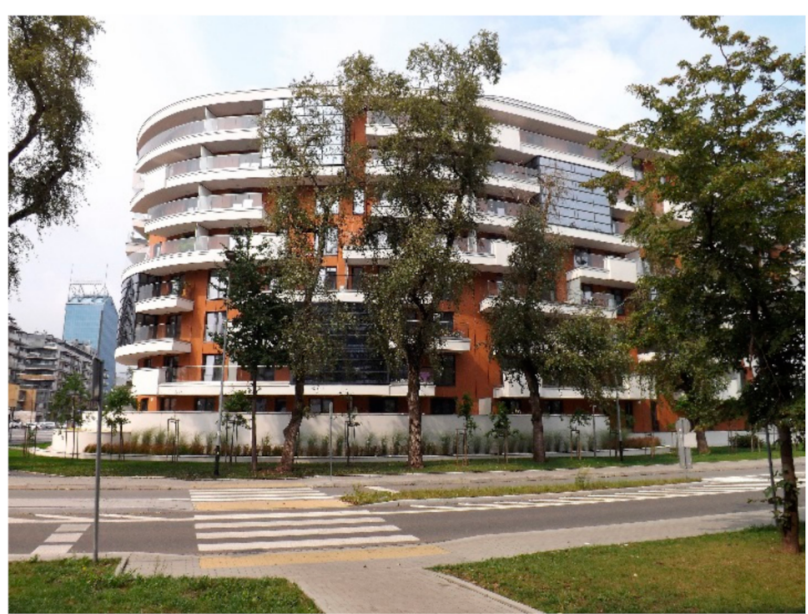

(b)

Figure 16. Grzegórzki- "international style" architecture of housing complexes with no connection to the local identity-as seen in 2020. Photo by authors. (a) view towards Wiślane Tarasy I complex; (b) Wiślane Tarasy II complex looking more like some resort in the Mediteranean, than a housing complex in Cracow.



(a)



(b)

Figure 17. Grzegórzki- public greenery around and within housing complexes-as seen in 2020. Photo by authors. (a) internal public passage with greenery; (b) publicly accessible greenery on the edge of one of the housing complexes.

The transformation of post-industrial areas in Zabłocie began almost simultaneously. However, it initially progressed at a slower pace [86], also because production and other economic activity, often relocated from other areas of the city, was still ongoing in many buildings that existed at the time. Another reason was the isolation of the district, which has the shape of the letter $\mathrm{V}$, surrounded on both sides by railway escarpments and by the Vistula River from the top (Figure 18). This area was connected with the remainder of the city's urban fabric by only three narrow streets. Only the construction of the previously mentioned bridge and tram line across the Vistula to Grzegórzki brought this area closer to the city, both mentally and functionally. Paradoxically, the resulting offer was first taken up by educational and cultural institutions, with housing complexes built primarily in the last five years. The district is the home of one of the largest private universities in the city-the Andrzej Frycz-Modrzewski Krakow University (since 2000) whose campus (2000-2020) is currently located near the river (initially, the university operated in office and post-industrial buildings scattered across the district). The adapted buildings of the former 'Rekord' Enamelware and Tin Products Factory, known from Steven Spielberg's 
film Schindler's List, became two important cultural institutions: a branch of the historical museum of the city of Cracow which relays the history of the area [106] and MOCAK-the Museum of Contemporary Art Kraków (since 2010).

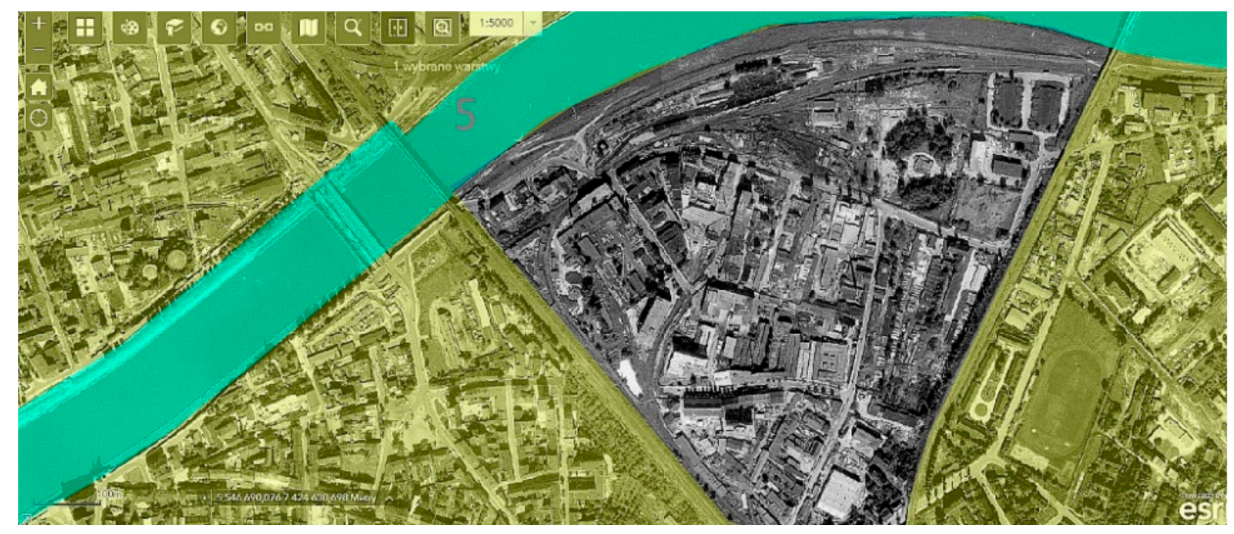

(a)



(b)

Figure 18. Comparison of orthophotomaps of the selected fragment of Cracow's urban fabric under study (5. Zabłocie) from 1970 (a) and 2019 (b) against public greenery (cyan). There is a visible change in the urban fabric's typology and density, based on aerial photography from: https://msip.krakow.pl.

In 2010, a local spatial development plan entered into force for the territory of Zabłocie. Its provisions, which are applicable to this day, have completely transformed the image of the district. Apart from a number of buildings in the municipal historic monuments record, the district's post-industrial architectural heritage was not placed under any form of conservation. Similarly, due to soil degradation, natural heritage was practically nonexistent. The plan introduced a regular grid with narrow blocks allowing high-density development and mixed-use housing and commercial or service buildings [107]. Two short pedestrian and recreational axes were delineated, with a small amount of greenery-at the back of the MOCAK and along one of the area's streets (Romanowicza).

The site is not connected with the urban greenery system. New buildings and complexes are consistently built by different real estate developers, based on designs by numerous architectural firms. Thousands of new apartments and workplaces are offered (Figure 19a,b). Many of them, due to the use of attractive details that bring industrial aesthetics to mind-with steel and brick or raw concrete- have managed to create an illusion of place-based atmosphere, different from the situation in Grzegórzki (Figure 20a). Certain post-industrial buildings, such as a mill from the start of the twentieth century and a six-storey factory hall from the 1970s (Figure 20b), were subjected to adaptive reuse, but most were demolished. At present, a rapid municipal railway stop has been modernised nearby. As is often the case, the city did not develop essential buildings-primary schools, kindergartens or public healthcare centres-that contribute to housing comfort. The private sector is trying to fill this gap, but so far this has proved insufficient. 


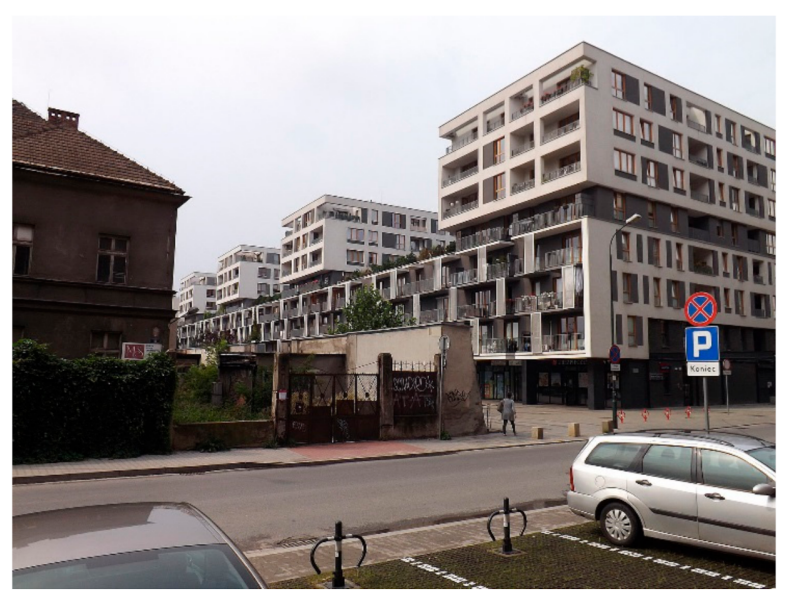

(a)

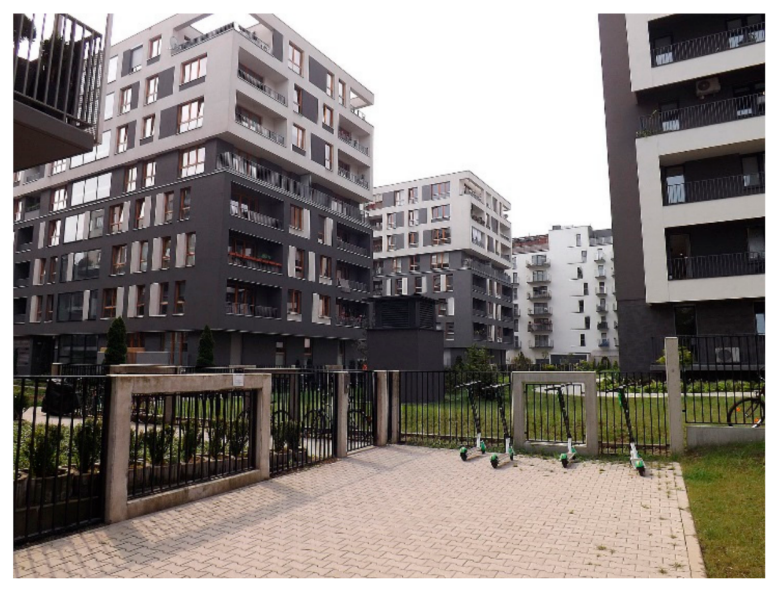

(b)

Figure 19. Zabłocie- selected housing projects—as seen in 2020. Photo by authors. (a) difference of scale and density between existing and new architecture; (b) internal green courtyards are accessible only for the inhabitants.



(a)

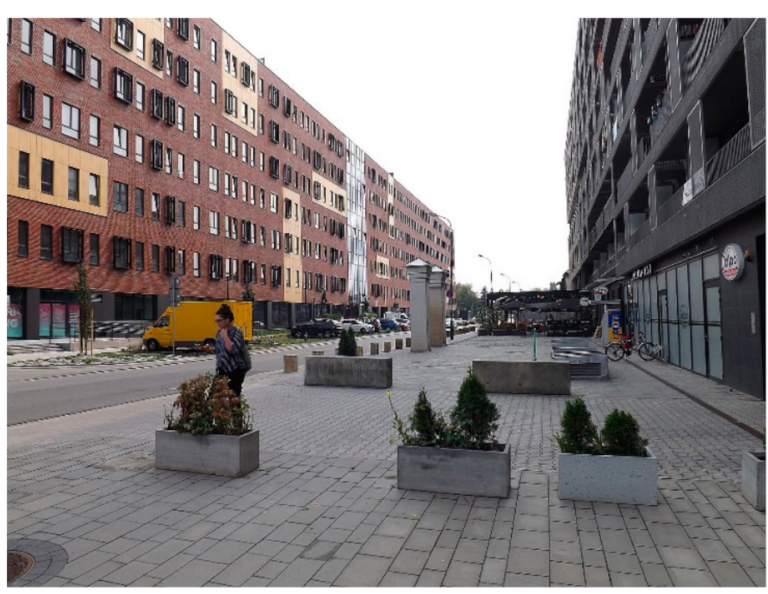

(b)

Figure 20. Zabłocie- selected housing projects—as seen in 2020. Photo by authors. (a) newly formulated street corner with shops in the ground floor; (b) public space of Romanowicza street with former factory adopted to apartment use (left).

In terms of conservation and offering access to natural heritage, the most important change in Grzegórzki was reconnecting this district with the river. The elimination of railway infrastructure that served industry began in the 1980s and led to the construction of pedestrian paths surrounded by greenery along the Vistula. They connect the existing boulevards at the level of Kazimierz with areas that are shaped more naturally and surround the Vistula in the eastern part of the city (also indirectly-with the Nowa Huta Meadows). The boulevards are modernised and equipped with new sports and recreation infrastructure elements from time to time (most recently-a beach in the eastern side of Kotlarski Bridge has been added). Zabłocie is still waiting for major projects near the Vistula boulevards, yet, similarly as in Grzegórzki, the railway lines that separated the district from the river have been demolished. A small green square called Stacja Wisła has been established in the western part of the area, and the banks of the river are currently more or less skilfully renaturalised [108].

\subsection{Main Findings}

The study was performed in a multi-track manner. The main criteria for evaluation were the number of elements of post-industrial heritage preserved; the preservation of 
the pre-existing genius loci in contemporary architectural interventions-such as forms, volumes of materials; the accessibility of semi-public or public spaces within the complex and access to elements of public greenery form the complex. Attention was mainly focused on functional and compositional linkages between the projects under study and elements of Cracow's blue-green infrastructure (Figure 21), understood as the natural heritage of the city. The distance to green areas and compositional linkages between the building/complex and the closest nearby park or river park were accounted for. It was also determined whether green areas were provided as a part of the housing complex projects as required by Polish construction law, as they can be found to constitute an attractive social space. It was also investigated whether they supplemented the urban system: providing passages, access paths or acting as continuations of the city's network understood as publicly accessible blue-green infrastructure. The elements of this infrastructure were divided into: crucial, moderate and local, due to the role which they play in forming the system (Table 1). The crucial elements are the ones, which are perceived as important in urban composition of the city, which has been also confirmed in many planning documents $[58,98]$ and publications $[37,96,97]$. They are used by all the inhabitants of the city and tourists as recreational zones. The "moderate" ones are usually used by the inhabitants and users of a particular district of the city (e.g., small park). The "local" ones are the smallest and the less important elements of the entire blue-green infrastructure of Cracow. Usually, they are used by inhabitants of one or few urban blocks (e.g., something like a local green playground or small garden).



Figure 21. Planned and existing city parks (red) and river parks (green and blue) in Cracow, set against housing projects in post-industrial areas under discussion (yellow)—based on: [17] www.bip. krakow.pl. 
Table 1. Areas under study and green areas (natural heritage) of the city.

\begin{tabular}{|c|c|c|c|c|c|c|}
\hline Name of Area & $\begin{array}{c}\text { Publicly } \\
\text { Accessible Green } \\
\text { Areas Featured } \\
\text { within the Project }\end{array}$ & $\begin{array}{l}\text { Compositionall } \\
\text { /Functiona } \\
\text { Linkages with } \\
\text { Urban } \\
\text { Greenery }\end{array}$ & $\begin{array}{c}\text { Number of } \\
\text { Public Green } \\
\text { Areas in Walking } \\
\text { Distance }\end{array}$ & $\begin{array}{l}\text { Name of the } \\
\text { Nearest Public } \\
\text { Green Area }\end{array}$ & Distance & $\begin{array}{l}\text { the Role of the } \\
\text { Nearest Public } \\
\text { Green Area in the } \\
\text { Blue-Green } \\
\text { System of the City }\end{array}$ \\
\hline Browar Lubicz & partially & yes & 3 & Park Strzelecki & $\begin{array}{c}25 \mathrm{~m} / \text { across the } \\
\text { street }\end{array}$ & moderate \\
\hline Wawrzyńca 21 & no & no & 1 & $\begin{array}{c}\text { Kurlandzki } \\
\text { Boulevard } \\
\text { (part of the Vistula } \\
\text { River Park) }\end{array}$ & $450 \mathrm{~m}$ & crucial \\
\hline $\begin{array}{c}\text { Nadwiślańska } \\
\text { Apartments }\end{array}$ & no & no & 2 & $\begin{array}{c}\text { Podolski Boulevard } \\
\text { (part of the Vistula } \\
\text { River Park) }\end{array}$ & $\begin{array}{c}12-50 \mathrm{~m} / \text { across } \\
\text { the street }\end{array}$ & crucial \\
\hline Grzegórzki & partially & yes & 2 & $\begin{array}{c}\text { Kurlandzki } \\
\text { Boulevard } \\
\text { (part of the Vistula } \\
\text { River Park) }\end{array}$ & $\begin{array}{l}12-20 \mathrm{~m} / \text { on the } \\
\text { southern edge } \\
\text { of the entire } \\
\text { complex }\end{array}$ & crucial \\
\hline Zabłocie & yes & partially & 2 & $\begin{array}{l}\text { Stacja Wisła Park } \\
\text { and Podolski } \\
\text { Boulevard } \\
\text { (part of the Vistula } \\
\text { River Park) }\end{array}$ & $\begin{array}{l}\text { 12-250 m/on } \\
\text { the northern } \\
\text { edge of the } \\
\text { entire complex }\end{array}$ & $\begin{array}{l}\text { crucial } \\
\text { (Boulevard) } \\
\text { and local } \\
\text { (park) }\end{array}$ \\
\hline
\end{tabular}

The smaller projects (Wawrzyńca 21 and Nadwiślańska Apartments) were found to offer no publicly accessible green areas on their grounds due to their size, composition and functional layout. They did not have compositional or functional linkages (except of visual) with the neighbouring elements of public greenery, because of the given location within the urban fabric. However, the bigger developments were found to feature such elements. The ones taken under consideration in this paper (Browar Lubicz or entire new parts of Grzegórzki and Zabłocie districts) are in fact multifunctional, with a predominant multifamily housing function. All of them are located close to elements of public greenery, which play different roles in the entire blue-green infrastructure system of Cracow (Scheme 2). The small complex within the adapted brewery offers partially accessible semi-public green squares within and opens towards Strzelecki Park with one of its visual and functional axes. Astonishingly, the two large multifunctional developments at Zabłocie and Grzegórzki districts, which are located almost at river embankments (river park) offered very little semi-public greenery to its users. In the case of Grzegórzki, only one public green passage was found (it is closed at night) which runs through one of the housing estates linking it to Kurlandzki Boulevard and the Vistula River. In Zabłocie, only two public passages with greenery were built to date (October 2020). In both cases, only the first line of the buildings forms the facade of river boulevards and have visual and compositional connections with the river and the river park.

The evaluation of the degree of preservation and exposure of post-industrial placebased heritage in the new projects was also an important element of the study. Apart from direct adaptations and preservation of existing build-up heritage elements, the form of inspiration for new architectural and material solutions was also taken into account. In heritage protection, including the protection of post-industrial heritage, Polish legislation provides useful tools in the listing of buildings and their complexes in historic monuments records and registers, especially the register of historical monuments (either municipal or voivodeship) [101,109], the establishment of conservation zones and detailed provisions in local spatial development plan (MPZP) texts. The last of the abovementioned tools can define a different method of protecting or maintaining characteristics that are valuable to local identity [110]. 


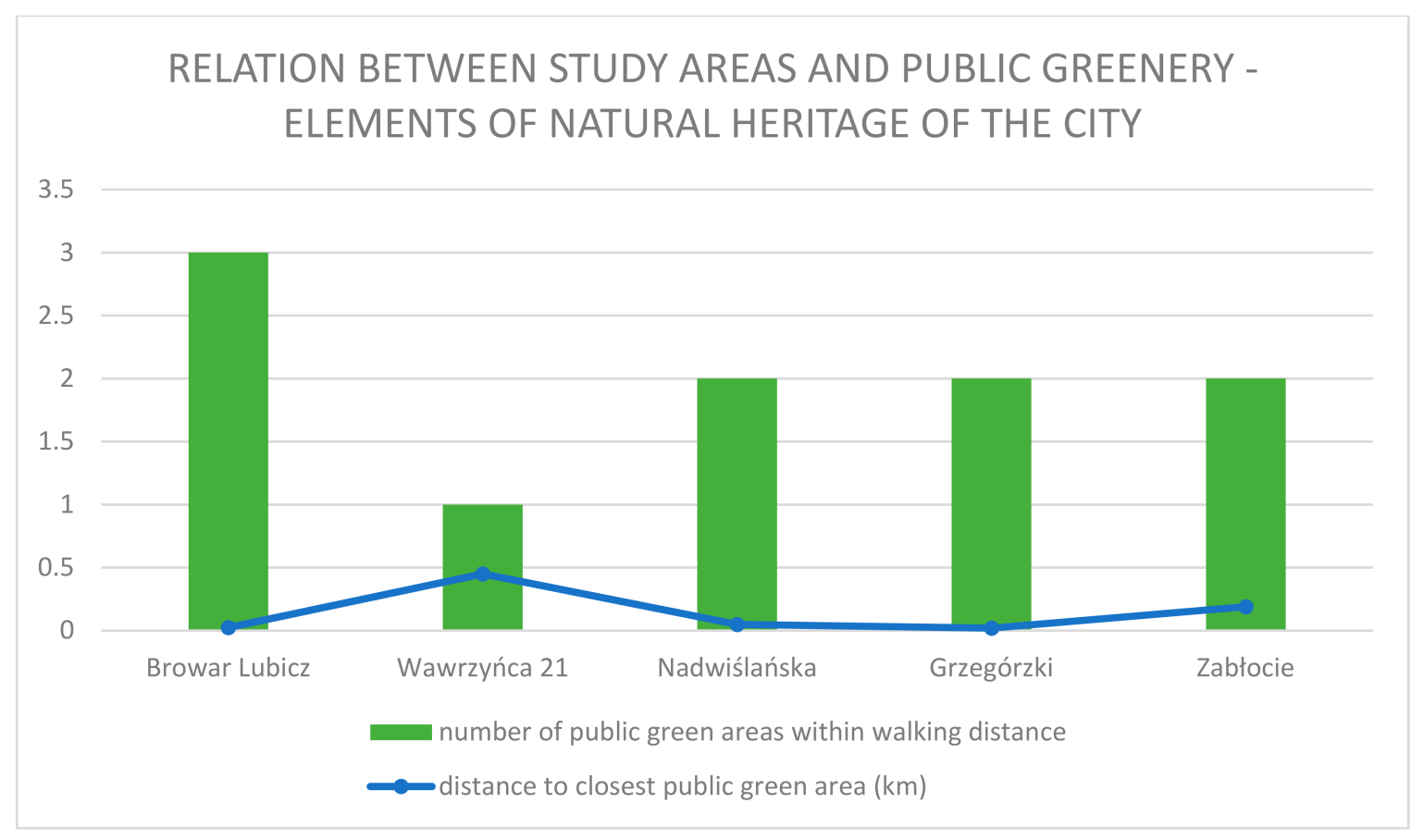

Scheme 2. The relation between areas under study and the elements of natural heritage.

Examining whether legal heritage protection instruments, together with those included in municipal planning documents, had an actual impact on the preservation and exposure of post-industrial relics in the areas under study, was also an important task. This is crucial, as Cracow, despite its long history and extensive heritage protection systems, possesses relatively few of such buildings and complexes in comparison to other large Polish cities.

In most of the areas under study, at least couple of instruments of heritage protection were incorporated. Browar Lubicz, Wawrzyńca 21, Nadwiślańska Apartments, the western part of Grzegórzki and most of Zabłocie districts are located within UNESCO protected areas of the city (the strictly protected zone or the buffer zone). Beyond these areas, the urban layouts of some of the parts of the city in which three of the analysed projects are located are placed in the municipal monuments register [93]. They include urban layouts of: the Wesoła district (no. A-650; since 16 February 1984)—for Browar Lubicz, where four buildings were registered separately (no. A-998; since November 1995); the Kazimierz district within the 'new town' with historical suburbs: Łaka Św. Sebastiana (St. Sebastian Meadow), Podbrzezie and Pola Kazimierzowskie, placed in the monuments register (no. A-1273/M; since 18 July 2011) -for Wawrzyńca 21; and the former town of Podgórze (no. A-608; since 26 October 1981)—for Nadwiślańska Apartments. The weakest protection of built-up heritage could be observed in the districts of Grzegórzki and Zabłocie, as analysed in the paper. Both were associated mainly with industrial production and storage up to the end of the twentieth century. As such, they were not a subject of interest to conservation offices at the time, especially that numerous buildings and structures dated back to no earlier than the beginning of the twentieth century. As such, and because of their manufacturing functions, they were not sufficiently protected. The historical monuments register has only three entries located in Grzegórzki. This number includes the post-Austrian fort complex (no. A-1048, since 20 February 1998), the three buildings of the former slaughterhouse (no. A-936, since 28 January 1993), which blend well with the commercial complex of Galeria Kazimierz, and the Socialist Realist building of the present-day Variete Theatre (no. A-1359/M, since 21 January 2014). Two factory halls from the first half of the twentieth century are still listed in the municipal monuments record [109], despite having been demolished during the construction of housing complexes in the early 2000s. None of the remains of the post-industrial past of Zabłocie district are 
listed in monuments register [101], despite the fact that almost the entire area has been protected by UNESCO as a buffer zone since 2010. Five factory complexes from 1899-1939, which were remodelled already in the interwar period and were listed the municipal monuments record [109] — and are currently also being remodelled and adapted to new uses. It includes two museums at Lipowa Street, apartments and offices in the mill at Zabłocie Street. The comparisons below demonstrate just how small the fragment of postindustrial heritage is that is under conservation in the analysed areas (Table 2, Scheme 3). The reference to the post-industrial heritage in new architecture were validated by the appearance of new buildings $[1,13,22,102,103]$. The use of materials, colours of the finishing of the facades, as well as details characteristic for industrial architecture in new structures was validated as "strong". The use of some (at least 2 ) of abovementioned elements in new buildings was validated as "medium". The lack of the references or small percentage of it (1 element) was evaluated as "weak".

Table 2. Areas under study analysed in terms of the protection of post-industrial architectural and urban heritage.

\begin{tabular}{cccc}
\hline Name of Area & $\begin{array}{c}\text { Degree of Heritage } \\
\text { Preservation and Exposure }\end{array}$ & $\begin{array}{c}\text { Number of Buildings/Complexes under } \\
\text { Conservatory Protection or with the } \\
\text { Status of Heritage Structures in } \\
\text { Planning Documents }\end{array}$ & $\begin{array}{c}\text { References to Post-Industrial } \\
\text { Heritage in New } \\
\text { Architecture }\end{array}$ \\
\hline Browar Lubicz & high & $\begin{array}{c}4 \text { buildings of the former brewery, } \\
\text { Urban layout of Wesoła district }\end{array}$ & strong \\
\hline $\begin{array}{c}\text { Nawrzyńca 21 } \\
\text { Apartments }\end{array}$ & high & Urban layout of Kazimierz district & strong \\
\hline Grzegórzki & none & Urban layout of Podgórze & strong \\
\hline Zabłocie & low & 3 entries in the municipal monuments \\
register & medium \\
\hline
\end{tabular}

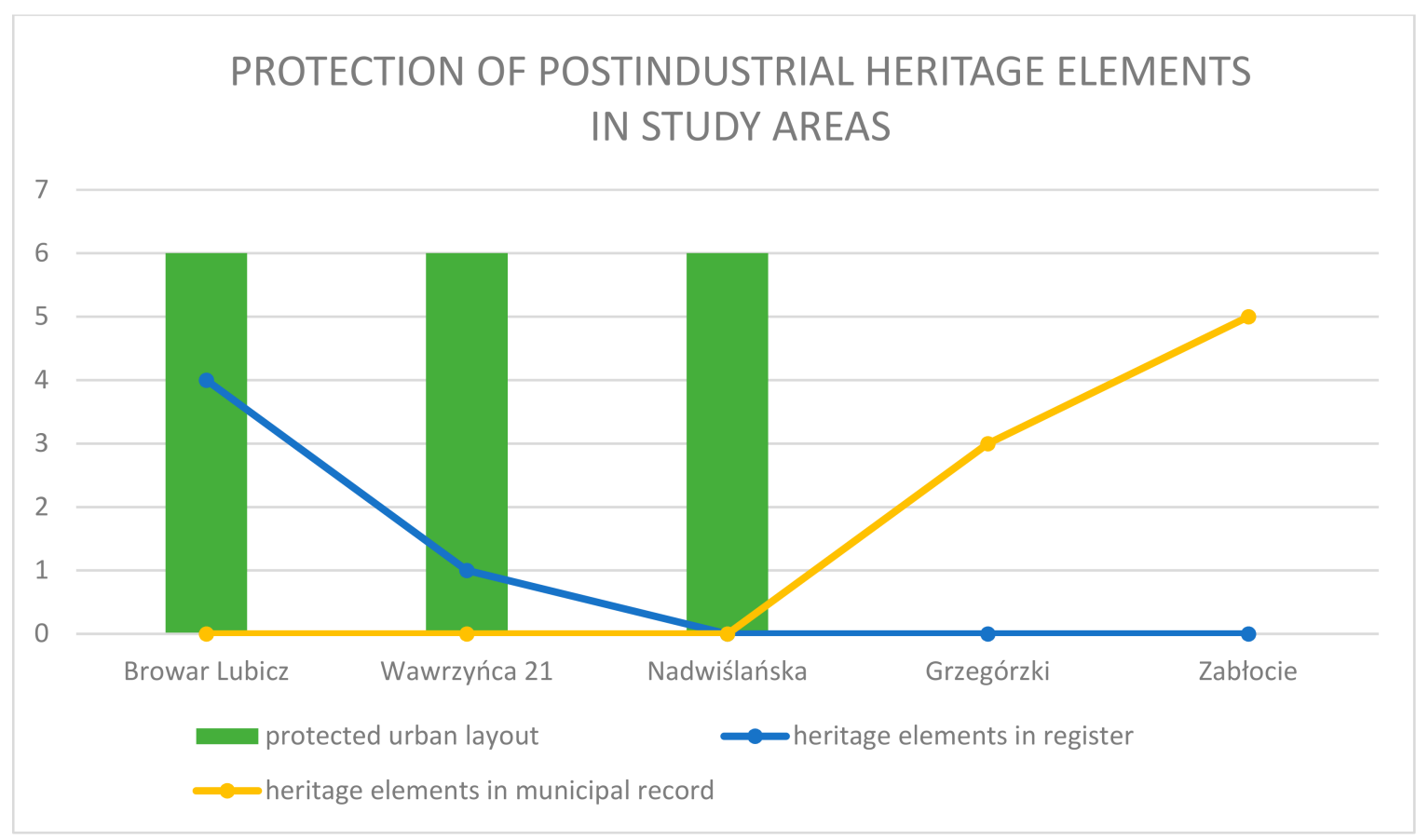

Scheme 3. The relation between the elements of protected cultural heritage areas under study. 
The territory of Cracow is covered by a Spatial Development Study that has been in force since 2003 and was updated in 2014 [98]. Another amendment to the Study has been in preparation since 2019. However, many areas of the city do not have local spatial development plans in place (or they have been voided). This leads to growing spatial chaos, as projects are approved on the basis of mutually uncoordinated planning permits. Most of the projects discussed in this paper were built in areas covered by local spatial development plans (Table 3). In some cases, these plans were introduced or changed after the beginning of 'revitalisation' works and merely sanctioned ongoing projects that were being built based on independent administrative proceedings.

Table 3. Areas under study and local spatial developments plans (MPZP).

\begin{tabular}{|c|c|c|c|c|c|}
\hline Name of Area & $\begin{array}{l}\text { Name of the Local } \\
\text { Spatial Development } \\
\text { Plan (MPZP) }\end{array}$ & $\begin{array}{c}\text { Date of Plan } \\
\text { Entering into Force }\end{array}$ & $\begin{array}{l}\text { Area Covered by } \\
\text { Local Spatial Plan } \\
\text { (in Hectares) }\end{array}$ & $\begin{array}{l}\text { Area under Study } \\
\quad \text { (in Hectares) }\end{array}$ & $\begin{array}{c}\text { Duration of } \\
\text { Design/Design and } \\
\text { Construction }\end{array}$ \\
\hline Browar Lubicz & MPZP ‘Browar Lubicz’ & 24 Oct.2007 & 2.23 & 2.23 & $\begin{array}{l}2004-2011 \\
2011-2013\end{array}$ \\
\hline Wawrzyńca 21 & MPZP ‘Bulwary Wisły' & 8 Oct. 2013 & 168.24 & 0.6 & 2006-2017 \\
\hline $\begin{array}{l}\text { Nadwiślańska } \\
\text { Apartments }\end{array}$ & MPZP ‘Bulwary Wisły' & 8 Oct. 2013 & 168.24 & 0.9 & 2011-2014 \\
\hline Grzegórzki & $\begin{array}{l}\text { I. Western part of the } \\
\text { area- MPZP 'Rejon Al. } \\
\text { Daszyńskiego' } \\
\text { II. No local plan for } \\
\text { eastern part }\end{array}$ & I. 22 Nov. 2018 & I. 45.7 & $\begin{array}{l}\text { I. } 12 \\
\text { II. } 22\end{array}$ & $\begin{array}{l}1994 \text { and still } \\
\text { ongoing }\end{array}$ \\
\hline Zabłocie & MPZP 'Zabłocie' & 26 June 2006 & 175 & 41 & $\begin{array}{l}2000 \text { and still } \\
\text { ongoing }\end{array}$ \\
\hline
\end{tabular}

The areas in the eastern part of the Grzegórzki district, which are located outside of the conservation zone associated with the Monument to History and UNESCO, are an exception. They were the only areas from among those under study not to have a local spatial development plan in place as of the time of writing of this paper (October 2020). Despite heavy development in the district. The lack of detailed planning documents and the often-vague provisions of the Study [98] caused the projects under analysis to contribute to the protection of cultural and natural heritage and the preservation of the genius loci to differing degrees. Most of the projects were initiated prior to the passing of current spatial planning and revitalisation acts and were designed and built under different legal conditions.

It should also be remembered the local spatial development plans [111,112] and municipal revitalisation documents $[99,113]$ change every couple of years and are not always mutually coherent. In terms of the protection of natural heritage, apart from the provisions of the study and local plans, a physiographic report prepared almost a decade ago can be a point of reference [17]. Therefore, numerous projects from the last two decades, even those in neighbouring areas, were built under different legal and spatial conditions - which applies particularly to the latest buildings, built in the context of previously completed projects (primarily in Zabłocie and Grzegórzki).

\section{Discussion}

Civilisational progress and technological development have always enforced changes in the use of urban space, primarily including architectural heritage, which forms the urban fabric [114]. It seems that it is widely accepted that historic structures in European cities and towns should be adapted to new functions, instead of being destroyed and demolished. In Poland, this way of thinking is not always associated with post-industrial heritage. As a result of global economic processes, during the last decades we could observe a disappearance of industrial production which used to determine the power and strong position of cities and region [37]. It has been transferred to other areas of the world. 
Thus, as stated at the beginning of the paper, many abandoned and unused complexes of buildings and engineering structures were left within the central districts of Polish major cities. They are evidence of the economic development of cities, mostly in nineteenth and twentieth century. Many monuments of post-industrial heritage frequently possess not merely historic but also considerable artistic value. Such complexes and singular buildings, which no longer serve their original functions, are adapted to different needs [115]. Multifamily housing is one of them [61-65]. This way of thinking is connected to guidelines resulting from the needs of sustainable development [35]. They advocate the necessity to reuse already urbanised brownfields in order to stop urban sprawl.

The research presented in this paper was focused on multi-family housing projects of different size, built on central, post-industrial sites. Cracow was chosen as a case study, as the authors have been conducting many research projects focused on it over the previous decades. Furthermore, various forms of conservation of built-up and natural heritage were applied in the city. Therefore, the authors were interested in investigating how they affected the character of architecture and land development in the renewed post-industrial areas under study.

In the case of listing the entirety of a city's fabric as a monument to history (as with the historic centre of Cracow), every new project must be approved by proper administrative organs (including conservation services). The provisions concerning conservation and exposure of surviving post-industrial heritage are typically quite restrictive in the areas under study, although in some cases they were introduced after the commencement or even the conclusion of new projects.

They are defined by provisions of local law (local spatial development plans) or listings of individual buildings and complexes in applicable monuments registers (at the municipal or voivodeship level). The revitalisation of post-industrial sites must nevertheless allow for a high degree of interference with and the transformation of surviving tissue $[49,52,54]$ especially as not all of its elements are under protection, since many of them are twentiethcentury factory and storage halls of negligible spatial and architectural value. However, it is also the awareness of developers, decision-makers and the talent of designers that define the degree to which the often-unique post-industrial character of these areas has been either preserved or lost. The findings of the study also showed that not all legal forms of heritage protection that are present in the Polish system are effective. Surprisingly, as proven in the study, only the combination of two legal instruments can effectively protect post-industrial and natural heritage: an entry in the monument register [101] together with an enacted local spatial development plan (Scheme 4). This holds true even despite the existence of UNESCO protection zones [93], which apply to large territories of the city centre of Cracow, so it seems to be equally protected. Practice has demonstrated that it is not the case (Table 4). The findings of the study open the way to further investigation. The COVID-19 pandemic has already changed the perspective and the way we use our cities $[116,117]$. The public sector and commercial businesses, which were the main actors in the refurbishment of post-industrial sites, will not need so many square metres within cities anymore. Most activity has already been switched to remote work. The question as to whether multi-family housing in converted, post-industrial sites can become a more efficient way of protecting this kind of heritage for the years to come, instead of adapting them to other functions, remains open. 




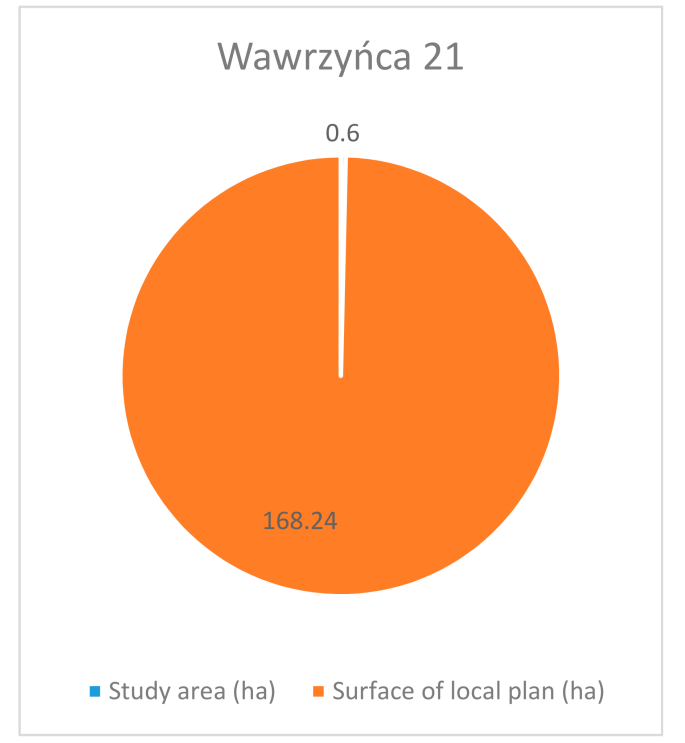

\section{Nadwiślańska Apartments}



- Study area (ha) = Surface of local plan (ha)

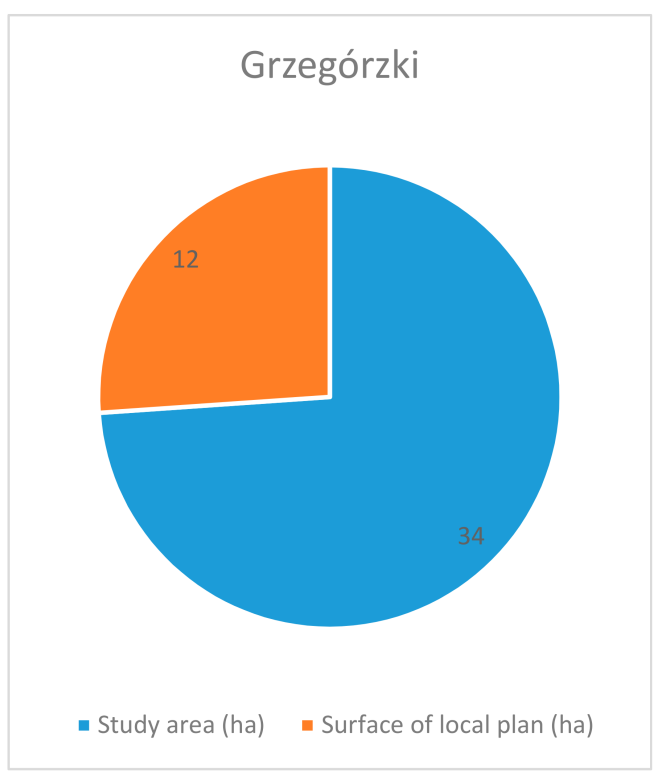



Scheme 4 . The relation between the local spatial development plans areas and the areas under study. 
Table 4. Summary of findings.

\begin{tabular}{cccc}
\hline Name of Area & $\begin{array}{c}\text { Degree of Cultural Heritage } \\
\text { Preservation and Exposure }\end{array}$ & $\begin{array}{c}\text { Degree of Linking of the } \\
\text { Building/Complex with Natural Heritage }\end{array}$ & $\begin{array}{c}\text { Role of Local Spatial Plan Provisions and } \\
\text { Conservation Documents in the Final } \\
\text { Project Outcome }\end{array}$ \\
\hline Browar Lubicz & High & High & Significant \\
\hline Wawrzyńca 21 & High & None & Significant \\
\hline $\begin{array}{c}\text { Nadwiślańska } \\
\text { Apartments }\end{array}$ & None & None & Average \\
\hline Grzegórzki & Low & Average & Insufficient \\
\hline Zabłocie & Low & Average & Average \\
\hline
\end{tabular}

The paper also focused on the formation of proper compositional and functional links between new projects and their spatial context [18,46], especially the city's publicly accessible green areas [98]. Therefore, this paper fills a gap in research on revitalised areas in the centres of Polish cities, primarily focusing on the links between the areas under study and elements of urban green-blue infrastructure of the city of Cracow [17], which constitutes its natural heritage in central areas. The results show that those linkages are connected primarily by the position of new projects, but also by properly drafted spatial development plans (Table 4). The case of new district in post-industrial areas of Zabłocie proves this statement. After demolishing most of pre-existing structures, the new district was built on an all but empty plot in last two decades. The potential to create good green public connectors between any given point of the site and the crucial element of blue-green infrastructure of the Cracow (Vistula River Park), neighbouring to the area, was squandered by deficient local development plan provisions [107].

\section{Conclusions}

Some of the residential buildings and complexes built in the twenty-first century in post-industrial areas in Cracow are located in dense urban fabric and do not feature any spatial, visual and functional linkages with the city's blue-green ecological system. It should therefore be stated that, based on the authors' studies and the literature, they were not found to offer a suitable housing environment. Detailed research presented in the paper on five post-industrial areas located in Cracow's city centre and where new projects with primarily multi-family residential functions were built, was as a part of a larger study conducted in five major Polish metropolises. One of the main criteria of the selection of these areas was their placement in close proximity to the city's blue-green infrastructure. Water and greenery are key elements of good quality housing environment [118]. The study found that despite this proximity, not all complexes were observed to have compositional and functional linkages with nearby public green areas. In two cases, these were found to be merely visual linkages, and in the third-only a part of the complex had these linkages and offered easy access to the elements of Cracow's natural heritage (Table 1). Green spaces in two complexes can be considered a continuation of urban greenery. In addition, the analysis of applicable planning documents (Table 3) demonstrated that local spatial development plans do not always require such linkages.

Examining the manner of post-industrial heritage protection was also an important aspect, focusing on architectural, urban and infrastructural heritage. The analyses of documents and an on-site urban analysis of the complexes under study found that not all forms of conservation proved effective. Only a listing in the historical monuments register, supported by spatial development plan provisions, guarantees the preservation of elements that are important to place-based tradition (Table 2andTable 3). They also become an inspiration for new architectural forms, which is visible in two of the examples under discussion (Browar Lubicz, Wawrzyńca 21). In two others (Nadwiślańska Apartments, Zabłocie), post-industrial heritage became an inspiration for architectural material solutions, but not necessarily formal ones or for the scale of the buildings and complexes. 
The complete loss of the spirit of the place in the eastern part of the district of Grzegórzki is a result of the weakness of conservation instruments that were to protect the area's post-industrial structures (Table 2). This also stems from the fact that this area, as the only one among the sites under study, was never covered by a local spatial development plan and all projects were erected based on construction permits issued on the basis of individual, uncoordinated administrative decisions. This led to a series of pathologies, e.g., the construction of a modern luxury building practically on top of the Vistula River's flood embankments, the deregulation of buildings lines and their height, or the predominance of paved areas over green ones in some complexes. This final aspect, this time legally sanctioned by local plans, is unfortunately visible in numerous projects in Zabłocie.

Elements of natural and cultural heritage that could aid in the correct shaping of the housing environment have only recently gained in significance in Poland. It is the talent of designers and will of real estate developers that largely determine whether they shall be put to proper use. The original research performed in the years 2000-2020 on Polish multifamily residential architecture proves that developers have started to pay greater attention to the quality of buildings and their surrounding spaces in recent years. The examples from Cracow presented above appear to confirm this statement. However, it should be remembered that the projects that were analysed are located in exceptional locations, where developers, expecting high profits [119], can provide additional, non-commercial value that stems from the exposure and conservation of heritage. This trend can be considered satisfactory.

The study and findings presented here concerned local cases from Cracow. Many elements of the development of post-industrial areas in Cracow (and other Polish cities) and, by extension, the outcome of the study, were affected by local legal conditions and the country's socio-economic situation. However, the urban analysis methodology and tools used in the study can be used to assess similar buildings and complexes all over the world [120]. They were often used by many scholars, including the authors themselves, for studies on other cities $[23,24,62,63]$.

Future research on Polish cases of introducing housing functions into post-industrial areas should account for the impact of new legal regulations at both state-level, such as the revitalisation act [69] and local level—new spatial development studies and local spatial development plans-on the transformation of other industrial areas in Polish cities. It should also focus on the manner of introducing housing functions is such areas. Interesting problems of the potential for creating a healthy housing environment in areas polluted by industry could result in interdisciplinary studies. This section of future research could go beyond Polish conditions and cover a wider, global context. Comparative studies of legal system impact on industrial heritage preservation in cities of Western Europe and Central and Eastern Europe could prove highly interesting. This is especially true when cities in countries with similar architectural traditions, common history and similar legal and political conditions in the nineteenth and twentieth century are accounted for (Poland, Czech Republic, Slovakia, Hungary, Austria, Eastern part of Germany, the Baltic States, Romania, Ukraine).

Author Contributions: Conceptualization, J.G. and M.G.; methodology, J.G.; validation, J.G. and M.G.; formal analysis, J.G. and M.G.; investigation, J.G. and M.G.; resources, J.G. and M.G.; data curation, M.G.; writing — original draft preparation, J.G. and M.G.; writing—review and editing, M.G.; visualization, M.G.; supervision, J.G. and M.G.; funding acquisition-J.G. and M.G. Both authors have read and agreed to the published version of the manuscript.

Funding: This publication has received financial support from the Polish Ministry of Science and Higher Education under subsidy for science for the FA CUT in 2019 and 2020.

Institutional Review Board Statement: Not applicable.

Informed Consent Statement: Not applicable. 
Data Availability Statement: Data available in a publicly accessible repositories of the different branches of the Office of the City of Cracow, as well as Małopolska Voivodship. They are all showed in "References" section.

Acknowledgments: The authors would like to thank the Spatial Planning Bureau of the Office of the City of Cracow for repeated access to illustrative material (Figure 4) from the project Model przestrzennej struktury miasta-Perspektwa planistyczna, prepared by M. Gyurkovich and associates in the years 2016-2017, which remains the property of the Office of the City of Cracow; We would also like to thank Józef Białasik of B2 Studio in Cracow, for sharing illustrations of the Wawrzyńca 21 project in Cracow (Figure 12, Figure 13, Figure 14). The authors would like to express their gratitude to Krzysztof Barnaś for the translation and proof-reading of the entire text on different stages of the paper's preparation and evaluation.

Conflicts of Interest: The authors declare no conflict of interest.

\section{References}

1. Rykwert, J. The Seduction of Place. The History and Future of Cities; Vintage Books: New York, NY, USA, 2002.

2. Mumford, L. The Culture of Cities, A Harvest Book Series; Harcourt Brace \& Company: San Diego, CA, USA, 1996.

3. Busquets, J. Barcelona, the Urban Evolution of a Compact City; Nicolodi; Harvard University Graduate School of Design: Cambridge, MA, USA, 2005

4. Sumara, A. Największe Miasta Świata-Ranking 2019, W Których Miastach Mieszka Więcej Niż 10 Mln Osób? Published on 17 March 2019. Available online: https://inzynieria.com/budownictwo/rankingi/48810,najwieksze-miasta-swiata-ranking-2019 (accessed on 16 August 2020).

5. World City Populations 2020. World Population Review. Available online: https://worldpopulationreview.com/world-cities (accessed on 16 August 2020).

6. European Commission, Directorate-General, Joint Research Centre, European Environment Agency. Urban Sprawl in Europe, The Ignored Challenge, (2006), EEA Report no. 10/2006. Available online: https:/ / www.eea.europa.eu/publications/eea_report_ 2006_10 (accessed on 14 August 2007).

7. Rose, J.F.P. The Well-Tempered City. What Modern Science, Ancient Civilizations and Human Nature Teach Us about the Future of Urban Life; Harper Collins Publishers: New York, NY, USA, 2017.

8. Salingaros, N. Principles of Urban Structure; Techne: Amsterdam, The Netherlands, 2005.

9. Nan, E. Good Urbanism. Six Steps to Creating Prosperous Places; Springer: New York, NY, USA, 2013.

10. Lowenthal, D. Natural and cultural heritage. Int. J. Herit. Stud. 2005, 11, 81-92. [CrossRef]

11. Pruszyński, J. Dziedzictwo Kultury Polski, Jego Straty i Ochrona Prawna; t. I-III; Kantor Wydawniczy Zakamycze: Kraków, Poland, 2001.

12. Veldpaus, L.; Pereira Roders, A.R.; Colenbrander, B.J.F. Urban Heritage: Putting the Past into the Future. Hist. Environ. Policy Pract. 2013, 4, 3-18. [CrossRef]

13. Kadłuczka, A. The Idea of Historic City. Heritage and Creation. Tech. Trans. Ser. Archit. 2015, 112, 29-39.

14. Schneider-Skalska, G. Healthy housing environment in sustainable design. IOP Conf. Ser. Mater. Sci. Eng. 2019, 471, 1-10. [CrossRef]

15. Kovarik, I. Novel urban ecosystems, biodiversity and conservation. Environ. Pollut. 2011, 159, 1974-1983. [CrossRef]

16. Smets, J.; De Blust, G.; Verheyden, W.; Wanner, S.; Van Acker, M.; Turkelboom, F. Starting a Participative Approach to Develop Local Green Infrastructure; from Boundary Concept to Collective Action. Sustainability 2020, 12, 107. [CrossRef]

17. Degórska, B. (Ed.) Opracowanie Ekofizjograficzne Miasta Krakowa; Urząd Miasta Krakowa, 2010-2011. Available online: www.bip.krakow.pl (accessed on 12 June 2017).

18. Lynch, K. Good City Form; The MIT Press: Cambridge, MA, USA, 1984.

19. Rossi, A. The Architecture of the City; Opposition Books; MIT Press: Cambridge, MA, USA, 1982.

20. Kriken, J.L.; Enquist, P.; Rapaport, R. City Building. Nine Planning Principles for the Twenty-First Century; Princeton Architectural Press: New York, NY, USA, 2010.

21. Schneider-Skalska, G.; Kusińska, E. (Eds.) Urban Housing Environment; Wydawnictwo Politechniki Krakowskiej: Kraków, Poland, 2017.

22. Gyurkovich, J. Architektura w Przestrzeni Miasta.Wybrane Problemy; Wydawnictwo Politechniki Krakowskiej: Kraków, Poland, 2010.

23. Gyurkovich, M. (Ed.) Future of the City: Mass HOUSING Estates or Multifamily Housing Complexes? Eco Rehab 3 Cracow 2012; Cracow University of Technology: Cracow, Poland, 2012.

24. Sotoca, A. (Ed.) After the Project-Updating Mass Housing Estates; II EcoRehab, Barcelona 2011; UPC: Barcelona, Spain, 2012.

25. Ilmurzyńska, K. Ewolucja przestrzenna Ursynowa Pótnocnego. PUA Przestrzeń Urbanistyka Architektura 2018, 2018, 203-218. [CrossRef]

26. Szczerek, E. Loss of potential: Large-panel housing estates-Czyżyny case. IOP Conf. Ser. Mater. Sci. Eng. 2019, 471, 1-10. [CrossRef]

27. Klumpner, H.; Twardoch, A.; Heciak, J. Miasto dobrze wymieszane. Archit. Murator 2017, 10, $32-40$. 
28. Bounds, M.; Morris, A. Second-wave gentrification in inner-city Sydney. Cities 2006, 23, 99-108. [CrossRef]

29. Haase, A.; Bontje, M.; Couch, C.; Marcinczak, S.; Rink, D.; Rumpel, P.; Wolf, M. Factors driving the regrowth of European Cities and the role of local and contextual impacts: A contrasting analysis of regrowing and shrinking cities. Cities 2021, 108, 1-11. [CrossRef]

30. Peterek, M.; Restrepo Rico, S.; Hebbo, Y.; Reichhardt, U.; Guerra Bustani, C. A flexible system for localised sustainable development. Tech. Trans. 2018, 9, 33-48. [CrossRef]

31. Peterek, M.; Restrepo Rico, S.; Hebbo, Y.; Reichhardt, U. Collaborative Planning for Sustainable Urban Infrastructure in Frankfurt am Main. Tech. Trans. 2019, 8, 31-50. [CrossRef]

32. Roca Cladera, J.; Biere Arenas, R.; Gyurkovich, M. (Eds.) Back to the Sense of the City: 11th VCT International Monograph Book; UPC CPSV: Barcelona, Spain, 2016; Available online: www.upcommons.upc.edu/handle/2117/90350 (accessed on 10 November 2016).

33. Zuziak, Z.; Grzybowski, A. (Eds.) Centra Miast Metropolitalnych w Polsce. Urbanistyka a Polityka Przestrzenna; Wyższa Szkoła Techniczna w Katowicach: Katowice, Poland, 2018.

34. Węcławowicz-Bilska, E. Recipe for a city. IOP Conf. Ser. Mater. Sci. Eng. 2019, 471, 1-10. [CrossRef]

35. Benedict, M.A.; McMahon, E.T. Green Infrastructure. Smart Conservation for 21st Century. Renew. Resour. J. 2002, $20,12-17$.

36. Miejski System Informacji Przestrzennej Krakowa (City System of Spatial Information of Cracow). Available online: https: / / msip.um.krakow.pl (accessed on 31 March 2020).

37. Encyklopedia Krakowa; PWN: Warszawa-Kraków, Poland, 2000.

38. Bogdanowski, J. Warownie i zieleń Twierdzy Kraków; Wydawnictwo Literackie: Kraków, Poland, 1979.

39. Sykta, I. Spacial Plans of the City of Krakow. Tech. Trans. Ser. Archit. 2008, 104, 51-67.

40. Gyurkovich, J.; Matusik, A.; Suchoń, F. (Eds.) Cracow: Selected Problems of the Urban Structure Evolution; Wydawnictwo Politechniki Krakowskiej: Kraków, Poland, 2016.

41. Seibert, K. Plan Wielkiego Krakowa; Wydawnictwo Literackie: Kraków, Poland, 1983.

42. Cullen, G. The Concise Townscape; The Architectural Press: London, UK, 1986.

43. Łakomy, K.; Hodor, K. About the changeability of the beauty criterion using selected industrial and sacral landscapes (18th-21st Centuries). Space Form 2016, 26, 349-360. [CrossRef]

44. Paszkowski, Z. Miasto Idealne w Perspektywie Europejskiej i Jego Związki z Urbanistyka; Universitas: Kraków, Poland, 2011.

45. Norberg-Schultz, C. Genius Loci-Towards a Phenomenology of Architecture; Rizzoli: New York, NY, USA, 2000.

46. Gyurkovich, J. Urbanity of a city-The dream of the past. Tech. Trans. Ser. Archit. 2015, 112, 97-114.

47. Sudjic, D. The Language of Cities; Penguin: London, UK, 2017.

48. Smętkowski, M.; Celińska-Janowicz, D.; Wojnar, A. Location patterns of advanced producer service firms in Warsaw: A tale of agglomeration in the era of creativity. Cities 2021, 108, 1-14. [CrossRef]

49. Eisinger, A.; Seifert, J. (Eds.) Urban RESET: How to Activate Immanent Potentials of Urban Spaces; Birkhäuser: Basel, Switzerland, 2012.

50. Davies, N. God's Playground: A History of Poland; Volume 1: The Origins to 1795; Volume 2: 1795 to the Present; Oxford University Press: Oxford, UK, 1981.

51. Racon-Leja, K. Impact of wartime destruction and post-war politics on the social reconstruction of a modern city-on the example of Magdeburg. IOP Conf. Ser. Mater. Sci. Eng. 2019, 471, 1-10. [CrossRef]

52. Kaczmarek, S. Rewitalizacja Terenów Poprzemystowych: Nowy Wymiar w Rozwoju Miast; Wydawnictwo Uniwersytetu Łódzkiego: Łódź, Poland, 2001.

53. Wyżykowski, A.; Kwiatkowski, K.; Racon-Leja, K. (Eds.) The Transformation of the City Space on the Background of Political-economic Changes; Institute of Urban Design Cracow University of Technology: Cracow, Poland, 2002.

54. Zuziak, Z.K. Revitalization of cities and the theory of urbanism. Tech. Trans. Ser. Archit. 2012, 109, 7-18.

55. Lorens, P.; Mironowicz, I. (Eds.) Wybrane Teorie Wspótczesnej Urbanistyki; Miasto-Metropolia-Region, Akapit-DTP: Gdańsk, Poland, 2013.

56. Urban Agenda for the EU 'Pact of Amsterdam'; Agreed at the Informal Meeting of EU Ministers Responsible for Urban Matters on 30 May 2016 in Amsterdam, The Netherlands. Available online: https://ec.europa.eu/regional_policy/sources/policy/ themes/urban-development/agenda/pact-of-amsterdam.pdf (accessed on 2 August 2020).

57. Ustawa z dn. 27 Marca 2003 Roku o Planowaniu I Zagospodarowaniu Przestrzennym z Późniejszymi Zmianami. Tekst Jednolity Dz. U. z 2020 r., poz. 293,471,782,1086 (Spatial Planning and Development Act of 27 March 2003, as Amended; Codified Text, Dz. U. 2020, item 293,471,782,1086). Available online: http:/ /isap.sejm.gov.pl/isap.nsf/download.xsp/WDU20200000293/U/D20200 293Lj.pdf (accessed on 2 August 2020).

58. Gyurkovich, M.; Szarata, A.; Zuziak, Z.K.; Ogrodnik, D.; Faron, A.; Ziobro, A.; Poklewski-Koziełł, D.; Suchoń, F.; Tota, P.; Sotoca, A.; et al. Model Przestrzennej Struktury Krakowa. Perspektwa Planistyczna. Etap IIZdefiniowanie Modelu Przestrzennej Struktury Krakowa; Reaserch project for BPP UM Kraków, Instytut Projektowania Urbanistycznego, Wydział Architektury; Politechnika Krakowska: Kraków, Poland, 2017.

59. Orlenko, M.; Ivashko, Y.; Kobylarczyk, J.; Kuśnierz-Krupa, D. Ways of revitalization with the restoration of historical industrial facilities in large cities. The experience of Ukraine and Poland. Int. J. Conserv. Sci. 2020, 11, 433-450.

60. Franta, A. The Role of the restructuring of postindustrial areas in the creation of new kinds of metropolitan public spaces-The stimulating function of regulations. Tech. Trans. Ser. Archit. 2007, 104, 35-43. 
61. Gyurkovich, M. 22@Barcelona-The City of Knowledge Civilization. Tech. Trans. Ser. Archit. 2012, 109, 25-56.

62. Gyurkovich, J. Cologne-Revitalization of the former port of Rheinauhafen. Tech. Trans. Ser. Archit. 2011, 108, 25-46.

63. Gyurkovich, J. The livable place: Messestadt Riem-A new district of Munich. Hous. Environ. 2012, 10, 68-73.

64. Gyurkovich, J. Restoring destroyed urban structures. In Reuso. III Congreso Internacional sobre Documentación, Conservación, y Reutilización del Patrimonio Arquitectonico y Paisajistico; Palmero Iglesias, L.M., Ed.; UPV: Valencia, Spain, 2015; Available online: https:/ / riunet.upv.es/handle/10251/56060\# (accessed on 16 January 2016).

65. Franta, A.; Bojarowicz, A. From slums to a model example of revitalisation: Overcoming a difficult identity in the renewal process of the district of Hulme in Manchester. Tech. Trans. 2018, 115, 23-44. [CrossRef]

66. Poklewski-Koziełł, D. Role of waterfront areas and pocket parks in shaping of housing environment on the example of the Nordhavnen Housing Estate in Copenhagen. Hous. Environ. 2018, 24, 74-81. [CrossRef]

67. Korbel, W. Institution of land development plan-Valuation and expectations of changes in the eyes of the communal authorities of Poland. Pr. Studia Geogr. 2018, 63, 23-39.

68. Gyurkovich, J. Contemporary housing environment-In search for urban climate. Urbanity Archit. Files 2018, 46, 513-524.

69. Ustawa z dn.9 Października 2015 Roku o Rewitalizacji z Późniejszymi Zmianami; Tekst Jednolity Dz.U. z 2020 r., poz.802, 1086 (Revitalisation Act of 9 October 2015, as Amended; Codified Text Dz.U. 2020, Item 802, 1086). Available online: http: / /isap.sejm.gov.pl/isap.nsf/download.xsp/WDU20200000802/U/D20200802Lj.pdf (accessed on 2 August 2020).

70. Lipiński, J.; Lorens, P. Młode Miasto Gdańsk: Laboratorium Miejskich Procesów Rozwojowych; Monoplan: Warszawa, Poland, 2016.

71. Lorens, P. Shaping the new face of the Imperial Shipyard in Gdańsk. Space Form 2019, 40, 151-170.

72. Matusik, A.; Racon-Leja, K.; Gyurkovich, M.; Dudzic-Gyurkovich, K. Hydrourban spatial development model for a resilient inner-city. The example of Gdańsk. ACE Archit. City Environ. 2020, 15, 1-21. [CrossRef]

73. Żylski, T. Operacja rewitalizacja. Archit. Murator 2016, 1, 22-25.

74. Bardzińska-Bonenberg, T. On gentrification of historical districts in Poznan. Tech. Trans. Ser. Archit. 2012, 109, 43-52.

75. Lorens, P. (Ed.) Rewitalizacja miast w Polsce: Pierwsze Doświadczenia; Urbanista: Warszawa, Poland, 2007.

76. Konior, A.; Pokojska, W. Management of Postindustrial Heritage in Urban Revitalization Processes. Sustainability 2020, 12,5034 [CrossRef]

77. Haupt, P. Architectural education for primary school students mentored by university students. World Trans. Eng. Technol. Educ. 2019, 17, 454-458.

78. Rocznik Statystyczny Rzeczpospolitej Polskiej 2019, GUS, Opublikowano 23.12.2019, (Statistical Yearly of the Republic of Poland 2019, GUS, Published on 23.12.2019). Available online: https:/ / stat.gov.pl/obszary-tematyczne/roczniki-statystyczne/rocznikistatystyczne/rocznik-statystyczny-rzeczypospolitej-polskiej-2019,2,19.html (accessed on 16 August 2020).

79. Szpakowska-Loranc, E.; Matusik, A. Łódź-Towards a resilient city. Cities 2020, 107, 1-14. [CrossRef]

80. Kozłowski, S.; Wojnarowska, A. Rewitalizacja Zdegradowanych Obszarów Miejskich. Zagadnienia Teoretyczne; Wydawnictwo Uniwersytetu Łódzkiego: Łódź, Poland, 2011.

81. Załuski, D.; Waloryszak, K.; Żylski, T. Trzy dzielnice, trzy rewitalizacje. Archit. Murator 2016, 1, $26-38$.

82. Trzepacz, P.; Warchalska-Troll, A. (Eds.) Rewitalizacja Miast: Teoria, Narzędzia, Doświadczenia; IRM: Kraków, Poland, 2017.

83. Gyurkovich, M.; Sotoca, A. Quality of Social Space in Selected Contemporary Multifamily Housing Complexes in Poland's Three Biggest Cities. IOP Conf. Ser. Mater. Sci. Eng. 2019, 471, 1-11. [CrossRef]

84. Ustawa z dn. 13 Lutego 2020 o Zmianie Ustawy “Prawo Budowlane"; Tekst Jednolity Dz. U. z 2020 r. poz. 471, 695,782. (Act of 13 February 2020 on the Amendment of the Construction Law Act; Codified Text, Dz. U. 2020 item 471, 695,782). Available online: https:/ /isap.sejm.gov.pl/isap.nsf/download.xsp/WDU20200000471/U/D20200471Lj.pdf (accessed on 2 August 2020).

85. Bartkowicz, B. The role of spatial planning in the realisation of tasks of strategic transformations and in the activation of space. Tech. Trans. Ser. Archit. 2011, 108, 7-11.

86. Dudzic-Gyurkovich, K. Effect of accessibility in housing complexes on shaping of beauty in the urban environment. Selected examples from Cracow. In Teka Commission of Architecture, Urban Planning and Landscape Studies; Polish Academy of Science Branch Lublin: Lublin, Poland, 2018; Volume XIV, pp. 116-125.

87. Happach, M.; Żylski, T. Kto dziś kształtuje miasto? Architektura Murator 2016, 5, 32-40.

88. Raport-Stan Mieszkalnictwa w Polsce; Ministerstwo Rozwoju; Marzec 2020 (Report-The State of Housing in Poland; Ministry of Development; March 2020). Available online: https: / / www.gov.pl/web/rozwoj/raport-o-stanie-mieszkalnictwa (accessed on 2 August 2020).

89. Leśniak-Rychlak, D. Jesteśmy Wreszcie We Własnym Domu; Instytut Architektury: Kraków, Poland, 2019.

90. Stiasny, G. Typowo polska architektura mieszkaniowa. Architektura Murator 2014, 1, 30-39.

91. Ogłoszenia o Wynajem Mieszkania-15.08.2020 (Apartment Rental Advertisements-15.08.2020). Available online: http:/ /info, wyborcza.pl/temat/wyborcza/og\%C5\%82oszenia+o+wynajem+mieszkania (accessed on 15 August 2020).

92. Gyurkovich, M.; Dudzic-Gyurkovich, K.; Matusik, A.; Racon-Leja, K. Vistula River Valley in Cracow: From an urban barrier to a new axis of culture in the scale of the city. ACE Archit. City Environ. 2020, 15, 9913. [CrossRef]

93. Lista Światowego Dziedzictwa UNESCO (UNESCO World Heritage List). Available online: https://www.unesco.pl/kultura/ dziedzictwo-kulturowe/swiatowe-dziedzictwo/lista-swiatowego-dziedzictwa/ (accessed on 12 August 2020).

94. Porębska, A.; Godyń, I.; Radzicki, K.; Nachlik, E.; Rizzi, P. Built heritage, sustainable development, and natural hazards: Flood protection and UNESCO world heritage site protection strategies in Krakow, Poland. Sustainability 2019, 11, 4886. [CrossRef] 
95. Suchon, F. "The iron ring". The fortification system as the constituting factor in the hybrid structure of the city-fortress. In Hybrid Urban Structures; Gyurkovich, M., Ed.; Wydawnictwo Politechniki Krakowskiej: Kraków, Poland, 2016; pp. $183-205$.

96. Izdebski, A.; Szmytka, R. (Eds.) Ekobiografia Krakowa; ZNAK Horyzont: Kraków, Poland, 2018.

97. Zachariasz, A. Development of the system of the green areas of Krakow from the nineteenth century to the present, in the context of model solutions. IOP Conf. Ser. Mater. Sci. Eng. 2019, 471, 1-11. [CrossRef]

98. Studium Uwarunkowań i Kierunków Zagospodarowania Przestrzennego Miasta Krakowa (2003), Uchwała RMK Nr XII/87/03 z dnia 16 kwietnia 2003 r. Zmiana Studium Uwarunkowań i Kierunków Zagospodarowania Przestrzennego Miasta Krakowa, t. I-III, załącznik do Uchwały nr CXII/1700/14 Rady Miasta Krakowa z 9 lipca 2014r., Biuro Planowania Przestrzennego UM Krakowa, Kraków 2014 (2003 Spatial Development Study, Resolution of the Cracow City Council of 16 April 2003 No. XII/87/03 together with the update vol. I-III dated on 9 July 2014). Available online: https: / /www.bip.krakow.pl/?bip_id=1\&mmi=48 (accessed on 31 July 2020).

99. Adamczyk -Arns, G.; Wojnarowska, A.; Feresztyn, E.; Hultsch, F.; Hultsch, F. Lokalny Program Rewitalizacji Starego Miasta, zleceniodawca: Urząd Miasta Krakowa, (Old Town Local Revitalisation Programme, commissioned by: Office of the City of Cracow) BIG-STÄDTEBAU GmbH, Kronshagen, Germany, June 2008. Available online: https: / / www.google.com/search?q=lokalny+program+rewitalizacji+Stare+Miasto+Krak\%C3\%B3w+2008\&source=lnms\&tbm= isch\&sa=X\&ved=2ahUKEwjB5q_Lwp_rAhVK-aQKHQW7BpkQ_AUoAXoECAwQAw\&biw=1366\&bih=625 (accessed on 16 August 2020).

100. Waszczyszyn, E. Hospital in "the heart of the city". Tech. Trans. Ser. Archit. 2008, 105, 213-221.

101. Zespoły i Obiekty z Terenu miasta Krakowa Wpisane do Rejestru Zabytków (stan na lipiec 2020 r.) (Buildings and Complexes in Cracow Listed in the Register of Monuments-for July 2020). Available online: https:/ /www.wuoz.malopolska.pl/ rejestrzabytkow (accessed on 20 September 2020).

102. Suchon, F. The revitalization of a postindustrial structure in the centre of historical city. Case study. Hous. Environ. 2013, 12, 154-158.

103. Czapnik, W.; Wużyk, K. Browar Lubicz w Krakowie. Architektura-Murator 2014, 11, 74-82.

104. Gyurkovich, M. In Search of Urban Composition of Sub-Centres in Polycentric European Metropolises. ACE Archit. City Environ. 2012, 6, 251-264.

105. Gilewicz, W.; Lisowski, M. “Galeria Kazimierz"- Shopping and Commercial Center in postindustrial city fabric of Krakow. Tech. Trans. Ser. Archit. 2006, 103, 323-330.

106. Museum of Cracow-Oskar Schindler's Enamel Factory. Available online: http://www.mhk.pl/oddzialy/fabryka-schindlera (accessed on 20 May 2016).

107. Uchwała NR CXIII/1156/06 Rady Miasta Krakowa z Dnia 28 Czerwca 2006 r. w Sprawie Uchwalenia Miejscowego Planu Zagospodarowania Przestrzennego “Obszaru Zabłocie”-Ogłoszona w Dzienniku Urzędowym Województwa Małopolskiego NR 559, poz. 3534 z Dnia 19 Września 2006 r. (Resolution No. CXIII/1156/06 of the Cracow City Council of 28 June 2006 on the Passing of the Local Spatial Development Plan for the 'ZABŁOCIE' area, Announced in the Official Journal of the Lesser Poland Voivodeship No. 559, item 3534 of 19 September 2006. The Plan Has Been in Effect Since 20 October 2006). Available online: https:/ / www.bip.krakow.pl/?dok_id=14330 (accessed on 1 August 2020).

108. Blazy, R. Revitalization of riverside boulevards in Poland-A case study on the background of the European implementation. IOP Conf. Ser. Mater. Sci. Eng. 2019, 603, 1-6. [CrossRef]

109. Kraków-Gminna Ewidencja Zabytków (Cracow-Municipal Historic Monuments Record). Available online: https://www.bip krakow.pl/zalaczniki/dokumenty/n/281325/karta (accessed on 10 October 2020).

110. Dobosz, P. Paradigm of future changes in the system of legal protection of monuments and care over them in Poland. Wiad. Konserw. J. Herit. Conserv. 2015, 44, 78-84. [CrossRef]

111. Uchwała NR XXIV/292/07 Rady Miasta Krakowa z Dnia 24 Października 2007 r. w Sprawie Uchwalenia Miejscowego Planu Zagospodarowania Przestrzennego Obszaru “Browar Lubicz”, Ogłoszona w Dzienniku Urzędowym Województwa Małopolskiego NR 827, poz. 5405 z Dnia 28 Listopada 2007 r. (Resolution No. XXIV/292/07 of the Cracow City Council of 24 October 2007 on the Passing of the Local Spatial Development Plan for the "Browar Lubicz" Area, Announced in the Official Journal of the Lesser Poland Voivodeship No. 827 item 54505 of 28 November 2007. The Plan Has Been in Effect Since 27 December 2007). Available online: https:/ / www.bip.krakow.pl/?dok_id=19431 (accessed on 1 August 2020).

112. Uchwała NR LXXXI/1240/13 Rady Miasta Krakowa z Dnia 11 Września 2013 r. w Sprawie Uchwalenia Miejscowego Planu Zagospodarowania Przestrzennego Obszaru “Bulwary Wisły”-Ogłoszona w Dzienniku Urzędowym Województwa Małopolskiego z Dnia 27 Września 2013 r., poz. 5685. Plan Obowiązuje od Dnia 28 Października 2013 r. (Resolution No. LXXXI/1240/13 of the Cracow City Council of 11 September 2013 on the Passing of a Local Spatial Development Plan for the "Bulwary Wisły" Area, Announced in the Official Journal of the Lesser Poland Voivodeship of 27 September 2013, Item 5685. The Plan Has Been in Effect Since 28 October 2013). Available online: https:/ / www.bip.krakow.pl/?dok_id=58413 (accessed on 1 August 2020). 
113. Uchwała NR XXXVI/929/20 Rady Miasta Krakowa z Dnia 26 Lutego 2020 r. Zmieniająca Uchwałe nr LIX/1288/16 w Sprawie Przyjęcia Aktualizacji Miejskiego Programu Rewitalizacji Krakowa (Resolution No. XXXVI/929/20 of the Cracow City Council of 26 February 2020, on the Amendment of RESOLUTION No. LIX/1288/16 on Approving an Updated Version of the Cracow Municipal Revitalisation Programme). Available online: https://www.bip.krakow.pl/?dok_id=167\&sub_dok_id=167\&sub= uchwala\&query=id\%3D24824\%26typ\%3Du\&_ga=2.186729386.364313227.1597573055-787868020.1597573054 (accessed on 16 August 2020).

114. Kostof, S. The City Shaped: Urban Patterns and Meanings Through History; Thames \& Hudson: London, UK; New York, NY, USA, 1999.

115. Gyurkovich, M. Adaptations of historic structures for new functions—Part 1 -Selected examples from Madrid. J. Herit. Conserv. 2017, 50, 30-43. [CrossRef]

116. Hanzl, M. Urban forms and green infrastructure- the implications for public health during the COVID-19 pandemic. Cities Health 2020, 4, 1-6. [CrossRef]

117. Jasiński, A. Public space or safe space-Remarks during the COVID-19 pandemic. Tech. Trans. 2020, 117, 1-10. [CrossRef]

118. Seruga, W. Greenery and water in contemporary architectural and urban complexes. Hous. Environ. 2018, 22, 174-249. [CrossRef]

119. Nieruchomości-Online-pl—(Real Estate Sale Offers). Available online: https:// krakow.nieruchomosci-online.pl/ (accessed on 10 October 2020).

120. Bojanowski, K.; Lewicki, P.; Moya Gonzàlez, L.; Palej, A.; Spaziante, A.; Wicher, W. Elementy Analizy Urbanistycznej; Program Tempus JEN-3533; Wydawnictwo Politechniki Krakowskiej: Kraków, Poland, 1998. 